\title{
Protein and lipid homeostasis altered in rat macrophages after exposure to metallic oxide nanoparticles
}

\author{
Zahra Doumandji • Ramia Safar • Mélanie Lovera-Leroux • Sara Nahle • Hilary Cassidy • \\ David Matallanas • Bertrand Rihn • Luc Ferrari • Olivier Joubert
}

Received: 11 March 2019 /Accepted: 24 June 2019 / Published online: 27 July 2019

(C) The Author(s) 2019

\begin{abstract}
Metal oxide nanoparticles (NPs), such as $\mathrm{ZnO}$, $\mathrm{ZnFe}_{2} \mathrm{O}_{4}$, and $\mathrm{Fe}_{2} \mathrm{O}_{3}$, are widely used in industry. However, little is known about the cellular pathways involved in their potential toxicity. Here, we particularly investigated the key molecular pathways that are switched on after exposure to sub-toxic doses of $\mathrm{ZnO}, \mathrm{ZnFe}_{2} \mathrm{O}_{4}$, and $\mathrm{Fe}_{2} \mathrm{O}_{3}$ in the in vitro rat alveolar macrophages (NR8383). As in our model, the calculated $\mathrm{IC}_{50}$ were respectively 16 , 68, and more than $200 \mu \mathrm{g} / \mathrm{mL}$ for $\mathrm{ZnO}, \mathrm{ZnFe}_{2} \mathrm{O}_{4}$, and $\mathrm{Fe}_{2} \mathrm{O}_{3}$; global gene and protein expression profiles were only analyzed after exposure to $\mathrm{ZnO}$ and $\mathrm{ZnFe}_{2} \mathrm{O}_{4}$ NPs. Using a rat genome microarray technology, we found that 985 and 1209 genes were significantly differentially expressed in NR8383 upon $4 \mathrm{~h}$ exposure to $1 / 4 \mathrm{IC}_{50}$ of $\mathrm{ZnO}$ and $\mathrm{ZnFe}_{2} \mathrm{O}_{4} \mathrm{NPs}$, respectively. It is noteworthy that metallothioneins were overexpressed genes following exposure to both NPs. Moreover, Ingenuity Pathway
\end{abstract}

Electronic supplementary material The online version of this article (https://doi.org/10.1007/s10565-019-09484-6) contains supplementary material, which is available to authorized users.

Z. Doumandji $(\triangle) \cdot$ M. Lovera-Leroux $\cdot$ S. Nahle $\cdot$

B. Rihn $\cdot$ L. Ferrari $\cdot$ O. Joubert

Institut Jean Lamour, UMR 7198, CNRS-Université de Lorraine,

2 allée André Guinier, BP 50840, 54011 Nancy, France

e-mail: doumandji.zahra@gmail.com

\section{R. Safar}

Faculté de Médecine, INSERM UMR_S NGERE 954, Université de Lorraine, Vandœuvre-lès-Nancy, France

H. Cassidy · D. Matallanas

Conway Institute of Biomolecular and Biomedical Research, University College Dublin, Dublin, Ireland
Analysis revealed that the top canonical pathway disturbed in $\mathrm{NR} 8383$ exposed to $\mathrm{ZnO}$ and $\mathrm{ZnFe}_{2} \mathrm{O}_{4} \mathrm{NPs}$ was eIF2 signaling involved in protein homeostasis. Quantitative mass spectrometry approach performed from both NR8383 cell extracts and culture supernatant indicated that 348 and 795 proteins were differentially expressed upon $24 \mathrm{~h}$ exposure to $1 / 4 \mathrm{IC}_{50}$ of $\mathrm{ZnO}$ and $\mathrm{ZnFe}_{2} \mathrm{O}_{4} \mathrm{NPs}$, respectively. Bioinformatics analysis revealed that the top canonical pathways disturbed in NR8383 were involved in protein homeostasis and cholesterol biosynthesis for both exposure conditions. While VEGF signaling was specific to $\mathrm{ZnO}$ exposure, iron homeostasis signaling pathway was specific to $\mathrm{ZnFe}_{2} \mathrm{O}_{4}$ NPs. Overall, the study provides resource of transcriptional and proteomic markers of response to $\mathrm{ZnO}$ and $\mathrm{ZnFe}_{2} \mathrm{O}_{4}$ NP-induced toxicity through combined transcriptomics, proteomics, and bioinformatics approaches.

Keywords Zinc oxide nanoparticles · Zinc iron oxide nanoparticles · Iron oxide nanoparticles ·

Transcriptomics $\cdot$ Proteomics $\cdot$ NR8383

\section{Introduction}

At the nanoscale, matter is governed by quantum mechanics and could have new chemical and physical properties, different from the molecular counterpart (Schins et al. 2004). When the tiny size allows the nanoparticles (NPs) to be introduced into biological organisms by cellular internalization, the interaction NP-living takes place. This ability to interact makes 
NP a potent means of delivering and transporting substances at the cellular level to treat on a very small scale. In this way, industries tend to optimize new biological and biochemical applications. Contrariwise, the large specific surface area of NPs could induce severe adverse effects on the living, compared with their homologous macroscopic materials. Therefore, a deep analysis of cellular responses to nanomaterials is necessary before they can be safely used. It is in this perspective that we have studied the cytotoxic potential of $\mathrm{ZnO}, \mathrm{ZnFe}_{2} \mathrm{O}_{4}$, and $\mathrm{Fe}_{2} \mathrm{O}_{3}$ NPs.

Nanoparticles of metal oxides are expressed, used, and consumed in large quantities in many countries. They are part of components of cosmetics, medical, electronics, and food products. Consequently, humans are repeatedly exposed to various NPs via inhalation (respiratory), ingestion (oral), or dermal (cutaneous) routes.

Their wide use must be challenged for the potential negative effects they can produce. Thus, it is urgent to assess the risk of different exposures to nanoparticles. Indeed, the nanoparticle-living interaction could result in biological damages (Alhadlaq et al. 2015; Eidi et al. 2012; Singh and Lillard 2009; Yang et al. 2015).

Industry's reliance on nanotechnology involves the inhalation exposure of workers to multiple NPs within their manufactures. Although the human body has several barriers against the penetration of foreign inhaled substances, such as the nose that acts as a filter, some nanoparticles could be trapped in the pulmonary alveolar region (Oberdörster et al. 2005; Présumé et al. 2016). Thus, an interaction between NPs and pulmonary alveolar cells could occur (Buzea et al. 2007). In this context, this study allows us to analyze the cellular and molecular responses linked to the exposure of rat pulmonary alveolar cells (NR8383) to both $\mathrm{ZnO}$ and $\mathrm{ZnFe}_{2} \mathrm{O}_{4}$ NPs. NR8383 cells are relevant due to their immune functions and their ability of contact with foreign bodies (Hussain et al. 2012). In addition, experimental rat or mouse models have been validated by many studies as toxicity paradigm of airways (Ganguly et al. 2017; Gaté et al. 2017; Wallin et al. 2017). Moreover, in order to respect the three " $\mathrm{R}$ " of the ethical approach described by Russel and Burch in 1959 for reducing, replacing, and refining the use of animal testing, it seems important to develop in vitro models (Tannenbaum and Bennett 2015). In vitro study of different cell lines represents a promising tool for the implementing predictive devices of NPs (Alhadlaq et al. 2015). The present cellular model will help establish a correlation of deregulated genes and their associated molecular pathways and protein production to reveal the accentuated response biomarkers of $\mathrm{ZnO}$ and $\mathrm{ZnFe}_{2} \mathrm{O}_{4} \mathrm{NPs}$ on that particular biological system.

The potential toxic effects of $\mathrm{ZnO} N \mathrm{NP}$ are known to be related to their solubility (Prach et al. 2013). Indeed, $\mathrm{Zn}$ ions could have negative impact on cellular homeostasis because there is a large panel of metalloproteins which are zinc dependent (Andreini et al. 2006), e.g., transcription factors. Studies have shown that $\mathrm{Fe}_{2} \mathrm{O}_{3}$ NPs can induce cell death (Brunner et al. 2006), while other studies showed that $\mathrm{Fe}_{2} \mathrm{O}_{3}$ induces no cytotoxicity (Chusuei et al. 2013). The $\mathrm{ZnFe}_{2} \mathrm{O}_{4}$ NPs were the least studied of the NP panel studied here. Thus, there is a lack in the literature on the potential toxic effects of $\mathrm{ZnFe}_{2} \mathrm{O}_{4}$. In this paper, this study provides information about the cytotoxic potential and for the first time the gene expression profile and proteome changes of cells exposed to $\mathrm{ZnFe}_{2} \mathrm{O}_{4} \mathrm{NPs}$.

The aim of this study is (i) to evaluate and compare the cytotoxicity of $\mathrm{ZnO}, \mathrm{ZnFe}_{2} \mathrm{O}_{4}$, and $\mathrm{Fe}_{2} \mathrm{O}_{3} \mathrm{NPs}$ in rat macrophage alveolar NR8383 cells, (ii) to measure the deliverable dose of NPs to NR8383 cells, and (iii) to analyze in these cells the consequence of sub-toxic NPs exposure on transcriptome and proteome profiles.

\section{Materials and methods}

\section{Nanoparticles}

Uncoated zinc oxide $(\mathrm{ZnO}) \mathrm{NPs}$ were obtained from the Joint Research Center (JRCNM110). ZnO NPs main physicochemical characteristics were as follows: primary particle size of $158 \mathrm{~nm}$; specific surface area of $12 \mathrm{~m}^{2} / \mathrm{g}$ (Table 1). The zinc ferrite oxide NPs (NanoAmor ${ }^{\circledR}$ $\mathrm{ZnFe}_{2} \mathrm{O}_{4}$, NRCWE-021) were obtained from Dr. Ulla Vogel (National Research Center for the Working Environment, NRCWE, Copenhagen). The main physicochemical characteristics of NanoAmor ${ }^{\circledR} \mathrm{ZnFe}_{2} \mathrm{O}_{4} \mathrm{NP}$ containing 5-10 wt.\% $\mathrm{ZnO}$ and $10-15$ wt. $\% \mathrm{Fe}_{2} \mathrm{O}_{3}$ were as follows: particle size of $15-30 \mathrm{~nm}$ and specific surface area of $87.7 \mathrm{~m}^{2} / \mathrm{g}$ (Table 1). The iron oxide NPs (NanoAmor $\mathrm{Fe}_{2} \mathrm{O}_{3}$, NRCWE-018) were also from NRCWE (Copenhagen) with the following main physicochemical properties: particle size of $30-50 \mathrm{~nm}$; specific surface area of $27.7 \mathrm{~m}^{2} / \mathrm{g}$ (Table 1). 
Characterization of $\mathrm{ZnO}, \mathrm{ZnFe}_{2} \mathrm{O}_{4}$, and $\mathrm{Fe}_{2} \mathrm{O}_{3}$ nanoparticles

Dry nanopowders are extemporaneously suspended in deionized water at $2.56 \mathrm{mg} / \mathrm{mL}$ and then directly sonicated $(0.4 \mathrm{~mm}$, Hielsher Ultrasonics $)$ at $4{ }^{\circ} \mathrm{C}$ for $6 \mathrm{~min}$ at $30 \%$ of amplitude or $161 \mathrm{~J} / \mathrm{mL}$ (Cohen et al. 2013). Then, NPs were diluted to the desired concentrations in cell media (DMEM, Sigma-D1145) without fetal bovine serum (FBS). The average hydrodynamic size and the zeta potential of each NP were determined by dynamic light scattering (DLS) on a ZetaSizer ${ }^{\mathrm{TM}}$ (Malvern instruments, Malvern, UK). The characterizations on DLS were done directly after suspension in cell media at $6.25 \mu \mathrm{g} / \mathrm{mL}, 50 \mu \mathrm{g} / \mathrm{mL}$, and $200 \mu \mathrm{g} / \mathrm{mL}$.

The shape of the NPs was characterized by transmission electron microscopy (TEM). A drop of aqueous suspension of each NPs was poured onto carbo-coated copper grid and air-dried for transmission electron microscopy observations (ARM 200F microscope operating at $200 \mathrm{kV}$ ).

Cell culture and exposure

NR8383 alveolar rat macrophage cell line was obtained from the American Type Culture Collection (ATCC, USA) and was grown in DMEM supplemented with $15 \%$ heat-inactivated FBS, $4 \mathrm{mM}$ L-glutamine (SIGMA-G7513), and a mixture of antibiotic/antimycotic composed of $100 \mathrm{U} / \mathrm{mL}$ of penicillin, $100 \mu \mathrm{g} / \mathrm{mL}$ of streptomycin (SIGMA-P0781), and $0.25 \mu \mathrm{g} / \mathrm{mL}$ of amphotericin B (SIGMA-A2942), at $37{ }^{\circ} \mathrm{C}$ in a humidified mixture of air $(95 \%)$ and $\mathrm{CO}_{2}(5 \%)$.

For all experiments, cells were seeded $24 \mathrm{~h}$ before exposure to NPs at a density of $5 \times 10^{4}$ cells $/ \mathrm{mL}$. Cells were exposed to NPs in cell media without FBS. The different concentrations of NPs were mixed at room temperature to ensure homogeneity of the samples before exposure to cells. Cells not exposed to NPs served as controls in each experiment.

\section{Cell viability}

Lactate dehydrogenase ( $(\mathrm{DH})$ leakage was analyzed using the LDH assay (Roche-4744934001, Germany) following the manufacturer's instruction. Briefly, NR8383 cells were seeded at $5 \times 10^{4}$ cells $/ \mathrm{mL}$ in 96well plates and exposed to different concentrations ranging 0.2 and $7.2 \mathrm{~cm}^{2}$ of $\mathrm{ZnO}$ NPs per square centimeters of cells $\left(\mathrm{cm}^{2} / \mathrm{cm}^{2}\right), 1.7$ and $53.1 \mathrm{~cm}^{2} / \mathrm{cm}^{2}$ of $\mathrm{ZnFe}_{2} \mathrm{O}_{4}$, and 0.5 and $16.8 \mathrm{~cm}^{2} / \mathrm{cm}^{2}$ of $\mathrm{Fe}_{2} \mathrm{O}_{3} \mathrm{NPs}$. These specific surface concentrations are equivalent of mass concentrations of 6.25 and $200 \mu \mathrm{g} / \mathrm{mL}$. After $24 \mathrm{~h}$ of exposure, plates were centrifuged at $800 \times g$ for $10 \mathrm{~min}$ and $100 \mu \mathrm{L}$ of each supernatant were transferred to a new 96-well plate with a black bottom that was already prefilled with $100 \mu \mathrm{L}$ of the LDH reaction mixture. Extracellular medium was incubated for $30 \mathrm{~min}$ at room temperature, then $50 \mu \mathrm{L}$ of a stop solution was added and the absorbance was measured at $490 \mathrm{~nm}$ on a microplate reader. NR8383 cells treated with 5\% Triton were considered as positive control. Unexposed NR8383 cells were considered as negative control. NP cytotoxicity was expressed as the percent of LDH leakage measured in positive control cells. Dose-effect relationships were assessed by ANOVA and Dunett's test. $p$ values $<0.05$ were considered significant.

Metabolic activity was assessed using the WST-1 assay (Berridge et al. 1996) (Roche, 11644807001, USA), according to manufacturer's protocol. NR8383 cells were seeded at $5 \times 10^{4}$ cells $/ \mathrm{mL}$ in 96-well plates and exposed to different concentrations (6.25 to $200 \mu \mathrm{g} /$ $\mathrm{mL}$ ) of $\mathrm{ZnO}, \mathrm{ZnFe}_{2} \mathrm{O}_{4}$, and $\mathrm{Fe}_{2} \mathrm{O}_{3}$ NPs. After $24 \mathrm{~h}$ of exposure, WST-1 reagent was added to each well. Cells were incubated at $37^{\circ} \mathrm{C}$ for $2 \mathrm{~h}$. The absorbance of the solution was determined at $480 \mathrm{~nm}$ on a microreader (BioRad-iMARK). IC $_{50}$ was measured for each type of NPs according to Reed-Muench method (Reed and Muench 1938) from WST-1 results.

\section{Measure of internal dosimetry by ICP-OES}

Experiments were conducted on NR8383 cells to determine the amount of cytotoxic NPs in contact with the cell layers, whether inside or on the cells, after $24 \mathrm{~h}$ of exposure. In order to obtain the amount of material for reliable elementary determinations, the experiment was carried out on $1 \times 10^{6}$ cells $/ 5 \mathrm{~mL}$ in 6 -well plates and exposed to both $1 / 4 \mathrm{IC}_{50}$ and $\mathrm{IC}_{50}$ of $\mathrm{ZnO}$ and $\mathrm{ZnFe}_{2} \mathrm{O}_{4}$, knowing that the $\mathrm{IC}_{50}$ of $\mathrm{ZnO}$ and $\mathrm{ZnFe}_{2} \mathrm{O}_{4}$ on NR8383 were $0.51(16 \mu \mathrm{g} / \mathrm{mL})$ and $18.5 \mathrm{~cm}^{2} / \mathrm{cm}^{2}(68 \mu \mathrm{g} / \mathrm{mL})$, respectively. After $24 \mathrm{~h}$ of exposure, cells were centrifuged at a low speed of $300 \times \mathrm{g}$ for $10 \mathrm{~min}$, washed with $\mathrm{NaCl} 0.9 \%$, and resuspended in $500 \mu \mathrm{L} \mathrm{NaCl} 0.9 \%$. After mineralization with $12 \mathrm{~N} \mathrm{HCl}$ in microwaves from room temperature up to $180^{\circ} \mathrm{C}$, and then held at $180{ }^{\circ} \mathrm{C}$ for $15 \mathrm{~min}, \mathrm{Zn}$ and Fe were directly measured by using the 720-ES Inductively Coupled Plasma Optical 
Table 1 Physical-chemical properties of nanoparticles studied by Joint Research Center (JRC) or the National Research Centre for the Working Environment (NRCWE), in Denmark, Copenhagen

\begin{tabular}{llll}
\hline & $\mathrm{ZnO}$ & $\mathrm{ZnFe}_{2} \mathrm{O}_{3}$ & $\mathrm{Fe}_{2} \mathrm{O}_{3}$ \\
\hline NM-Code & $\mathrm{NM}-110$ & NRCWE-021 & NRCWE-018 \\
Manufacturer & JRC & NanoAmor & NanoAmor \\
Cat. Num. & JRCNM01100a & $5710 \mathrm{FY}$ & $2520 \mathrm{ZH}$ \\
Surface area $\left(\mathrm{m}^{2} / \mathrm{g}\right)$ & 12 & 87.7 & 27.7 \\
Purity $(\%)$ & Low impurities & $98.50 \%$ & $99 \%$ \\
Crystal form & Zincite & Cubic & Alpha \\
\hline
\end{tabular}

Emission Spectrometer (ICP-OES) (Varian, Belgium). Mass equivalents of $\mathrm{ZnO}\left(\mathrm{MW} \mathrm{81.38)}\right.$ and $\mathrm{ZnFe}_{2} \mathrm{O}_{4}$ (MW 241.07) in contact with cells have been calculated from the amount of Zn (MW 65.38) and Fe (MW 55.8) measured.

\section{RNA isolation and quantification}

To evaluate gene expression, total RNA was isolated from NR8383 cells exposed for $4 \mathrm{~h}$ to $1 / 4 \mathrm{IC}_{50}$ of each NP by using the RNA-Solv reagent (R6830-02, USA). Unexposed cells were used as control. RNA content was determined by measuring absorption at $260 \mathrm{~nm}$ using a spectrophotometer (Biotech-Biospec-Nano, Shimadzu). Optimal purity of RNA was ensured by determination of the 260/280 nm of an absorbance ratio A260/A280 > 1.8. RNA integrity was confirmed with the Agilent bioanalyzer 2100 and RNA 6000 Pico Labchip kit (Agilent Biotechnologies, Palo Alto, CA). The RNA integrity number (RIN) score cutoff of 8 was used to determine whether the RNA integrity was qualified or not.

\section{Microarray expression profiling}

The microarray experiments were designed to perform four biological replicates for $1 / 4 \mathrm{IC}_{50}$ dose for each cytotoxic NP. The cRNA synthesis from cDNA and Cy3-dye labelling, hybridization, and washing steps were carried out with $100 \mathrm{ng}$ of total RNA following the manufacturer's specifications (One-Color Microarray-Based Gene Expression Analysis, version 6.6, Agilent Technologies Inc., USA). Microarray slides were scanned by Agilent DNA microarray scanner (G2505C) by setting the following: (i) one color scan channel for $8 \times 60 \mathrm{k}$ array slides, (ii) scan area of $61 \times$ $21.6 \mathrm{~mm}$, (iii) scan resolution of $3 \mu \mathrm{m}$, (iv) dye channel to Green, (v) Tiff file dynamic range of 20 bits, and (vi) Green PMT to $100 \%$. The TIFF images files and the quantification of fluorescence signal were obtained using Agilent Feature Extraction software version 11.0.1.1 to extract raw data and obtain QC reports.

Transcriptomics data analysis

Data of the samples that pass quality control parameters were after subjecting to percentile normalization using GeneSpring GX 13.0 software (Agilent Technologies, UK). Genes were considered as differentially expressed with $p$ values $<0.001$ and fold change values of $>|1.5|$. Statistical analysis was performed using BenjaminiHochberg False Discovery Rate. Statistically significant gene changes in each NP group were analyzed in terms of their associated molecular/cellular functions and representation in canonical pathways using Ingenuity Pathway Analysis software (IPA, v.39480507, release date September 2017, Qiagen Bioinformatics, Redwood City, USA).

SP3 cell proteomics

Single-pot solid-phase-enhanced sample preparation (SP3), using commercially available carboxylatemodified magnetic beads, was employed to analyze the NR8383 cells global proteome (Hughes et al. 2014). Briefly, cells were exposed for $24 \mathrm{~h}$ to $1 / 4 \mathrm{IC}_{50}$ of $\mathrm{ZnO}$ and $\mathrm{ZnFe}_{2} \mathrm{O}_{4}$ NPs. Thereafter, cell disruption was performed in $6 \mathrm{M}$ urea, $2 \mathrm{M}$ thiourea, and $50 \mathrm{mM}$ MOPS containing lysis buffer. Samples were then reduced and alkylated by DTT and iodoacetamide (IAA) respectively. Both hydrophobic and hydrophilic Sera-Mag SpeedBead carboxylate-modified magnetic particles (GE Healthcare, cat nos. 65152105050250 and 
45152105050250) were mixed in a 1:1 ratio and were added to each sample. Once immobilized on the hydrophobic and hydrophilic carboxylatemodifed magnetic beads, proteins and peptides were rinsed with a combination of ethanol and acetonitrile mixture to efficiently remove contaminating agents. After rinsing, proteins and peptides are eluted from the magnetic beads by adding a mass spectrometry (MS) solution (Fisher Scientific, cat no. 12321D).

Mass spectrometry and proteomic analysis

Each sample out the three biological replicates was run in triplicate on a Thermo Scientific Q Exactive mass spectrometer connected to a Dionex Ultimate 3000 (RSLCnano) chromatography system. Each sample was loaded onto a fused silica emitter (75 $\mu \mathrm{m}$ ID), using a laser puller (Sutter Instruments P2000, Novato, CA, USA), packed with Reprocil Pur (Dr Maisch, Ammerbuch-Entringen, Germany). Peptides were trapped on C18 columns $(1.9 \mu \mathrm{m}$; $12 \mathrm{~cm}$ in length). Tryptic peptide elution was performed with a gradient of mobile phase media with 0.1 of formic acid and was separated by an increasing acetonitrile gradient over $60 \mathrm{~min}$ at a flow rate of $250 \mathrm{~nL} / \mathrm{min}$ direct into a Q-Exactive MS. The MS was operated in positive ion mode with a capillary temperature of $320{ }^{\circ} \mathrm{C}$, and with a potential of $2300 \mathrm{~V}$ applied to the frit. All data were acquired while operating in automatic datadependent switching mode. A high-resolution $(70,000)$ MS scan $(300-1600 \mathrm{~m} / \mathrm{z})$ was performed using the Q Exactive to select the 12 most intense ions prior to MS/MS analysis using high-energy collision dissociation (HCD). Data acquisition for protein identification and quantification was done by MaxLFQ (Cox et al. 2014) searching with the MaxQuant version 1.5 reference proteome database (Uniprot). Modifications included C carbamylation (fixed) and $\mathrm{M}$ oxidation (variable). We used three biological replicate experiments per condition to ensure the quality of the quantification results. Two ratios of the intensities of the peptides with adjusted $p$ value less than 0.05 were used to determine the expression ratio for each protein between exposed and control samples. Ratios over 1.5 and less than 1 were selected.

\section{Results}

Zinc, zinc iron, and iron oxide nanoparticle properties

To explore the effects of zinc and iron particles in vitro, the morphology of $\mathrm{ZnO}, \mathrm{ZnFe}_{2} \mathrm{O}_{4}$, and $\mathrm{Fe}_{2} \mathrm{O}_{3} \mathrm{NPs}$ was assessed by TEM. The sample of $\mathrm{ZnO}$ particles (Fig. 1a, b) exhibited as expected a diversity of forms such as rectangular, rod, spherical, and irregular shapes, whereas $\mathrm{ZnFe}_{2} \mathrm{O}_{4}$ NPs displayed a combination of the spherical shape specific to the $\mathrm{Fe}_{2} \mathrm{O}_{3}$ NPs and nanosheets specific to $\mathrm{ZnO}$ NPs (Fig. 1c, d). $\mathrm{Fe}_{2} \mathrm{O}_{3}$ NPs revealed a spherical shape (Fig. 1e, f). Characterization of NPs in DMEM FBS-free was measured by DLS that is widely used to determine the size of Brownian NPs in colloidal suspension (Lynch and Dawson 2008). Indeed, measured secondary sizes represented by the hydrodynamic diameters $\left(D_{\mathrm{H}}\right)$ (Table 2) were as follows: $296 \pm 4,283 \pm 36$, and $357 \pm 8 \mathrm{~nm}$ for the ZnO NPs at respectively concentrations of $6.25,50$, and $200 \mu \mathrm{g} / \mathrm{mL}$. At the same increasing concentrations, (i) $\mathrm{ZnFe}_{2} \mathrm{O}_{4} D_{\mathrm{H}}$ were $71 \pm 18,224 \pm 14$, and $338 \pm 23 \mathrm{~nm}$; (ii) $\mathrm{Fe}_{2} \mathrm{O}_{3} D_{\mathrm{H}}$ were $133 \pm 3,144 \pm 2$, and $137 \pm 1 \mathrm{~nm}$. Furthermore, at the same concentrations, zeta-potential were (i) for $\mathrm{ZnO}-19 \pm 1,-13$, and $31 \mathrm{mV}$; (ii) for $\mathrm{ZnFe}_{2} \mathrm{O}_{4}-17,-23$, and $-21 \mathrm{mV}$; (iii) for $\mathrm{Fe}_{2} \mathrm{O}_{3} 27 \pm 1,6$, and $36 \mathrm{mV}$. The results of $D_{\mathrm{H}}$ characterization by DLS, at the lowest concentration $(6.25 \mu \mathrm{g} / \mathrm{mL})$, were the closest to the primary size characterization by TEM for all NPs. Indeed, by increasing concentration, it is likely that agglomerates are formed. It is important to mention that the specific surface area of $\mathrm{ZnFe}_{2} \mathrm{O}_{4}$ was 3.1 times higher than the one of $\mathrm{Fe}_{2} \mathrm{O}_{3} \mathrm{NPs}$ and 7.3 times higher than the one of $\mathrm{ZnO}$ NPs (Table 1).

$\mathrm{ZnO}$ and $\mathrm{ZnFe}_{2} \mathrm{O}_{4}$ nanoparticles reduced the viability of NR8383 cells

The potential cytotoxicity of the three NPs on NR8383 cells after $24 \mathrm{~h}$ of exposure was determined by measurements of LDH leakage and WST-1 assay. When the plasma membrane is impaired, LDH diffuses into extracellular media, and extracellular LDH increases with the extent of cytotoxicity of the NP. In each experiment, the positive control was triton-exposed NR8383 cells. A dose-dependent LDH leakage was observed for $\mathrm{NR} 8383$ cells exposed to $\mathrm{ZnO}$ and $\mathrm{ZnFe}_{2} \mathrm{O}_{4} \mathrm{NP}$ up to $50 \mu \mathrm{g} / \mathrm{mL}$. Cells exposed to $50 \mu \mathrm{g} / \mathrm{mL}$ of $\mathrm{ZnO}$ and $\mathrm{ZnFe}_{2} \mathrm{O}_{4}$ displayed respectively 75 and $50 \%$ increases of extracellular LDH, a dose reaching a plateau. One 

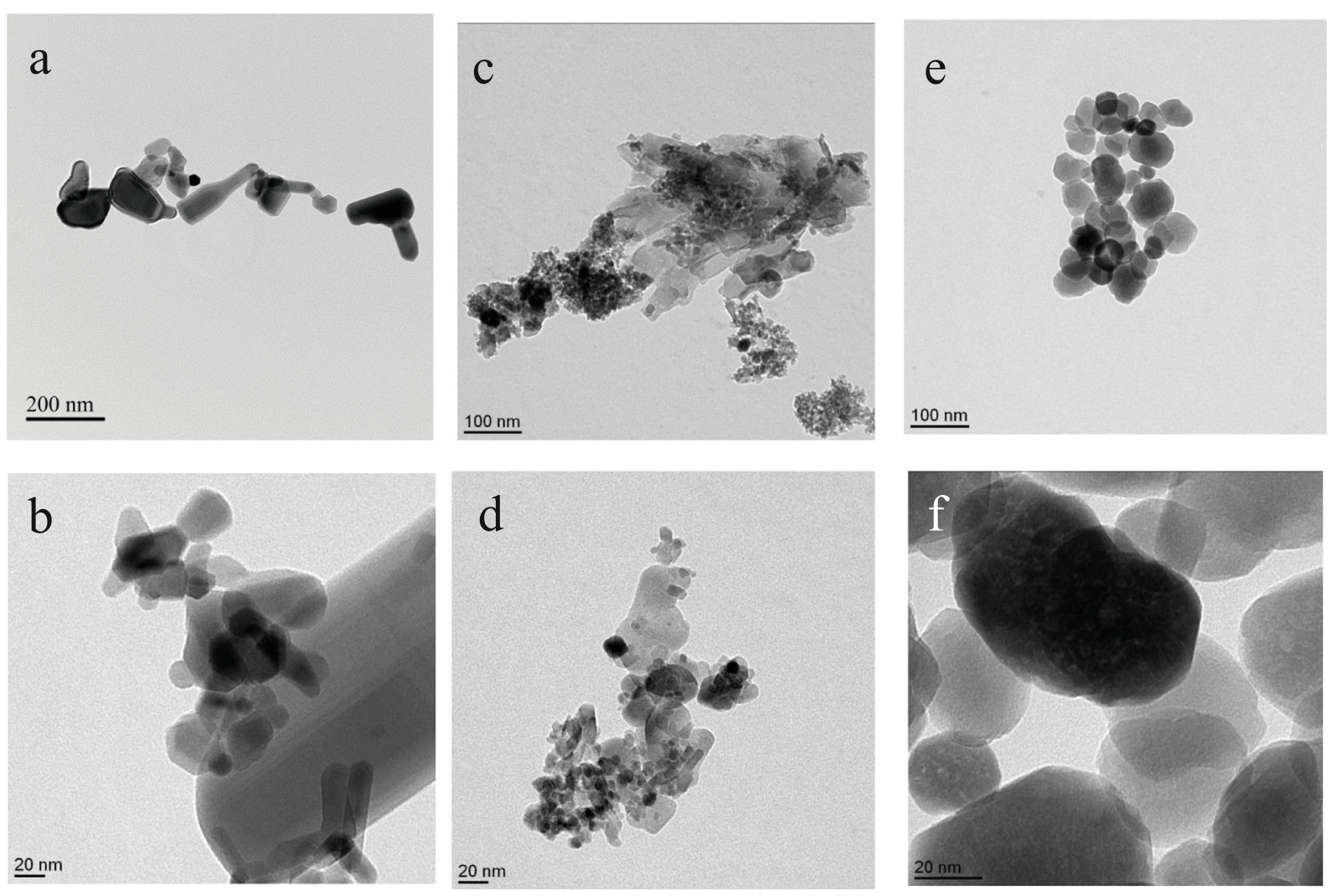

Fig. 1 Transmission electron microscopy images of zinc oxide NPs $(\mathbf{a}, \mathbf{b})$, zinc iron oxide $(\mathbf{c}, \mathbf{d})$, and iron oxide (e, f)

should notice that only the highest dose of $\mathrm{Fe}_{2} \mathrm{O}_{3}$ induced a $30 \%$ release of LDH (Fig. 2a). In conclusion, among the three NPs, $\mathrm{ZnO}$ exhibited the highest cytotoxic effect on NR8383 cell membrane, thus conferring for $\mathrm{ZnO}$ the highest toxic potential despite the lowest specific surface area.

WST-1 assay measures the metabolic activity by giving different absorption spectra of formazan formed by

Table 2 Hydrodynamic diameter $\left(D_{\mathrm{H}}\right)$ and zeta-potential $(\zeta)$ of $\mathrm{ZnO}, \mathrm{ZnFe}_{2} \mathrm{O}_{3}$, and $\mathrm{Fe}_{2} \mathrm{O}_{3}$ by dynamic light scattering (DLS)

\begin{tabular}{|c|c|c|c|}
\hline & $\mathrm{ZnO}$ & $\mathrm{ZnFe}_{2} \mathrm{O}_{4}$ & $\mathrm{Fe}_{2} \mathrm{O}_{3}$ \\
\hline \multicolumn{4}{|c|}{$6.25 \mu \mathrm{g} / \mathrm{mL}$ NPs in cell medium } \\
\hline$D_{\mathrm{H}}(\mathrm{n} \mathrm{m})$ & $296 \pm 4$ & $71 \pm 18$ & $133 \pm 3$ \\
\hline$\zeta(\mathrm{mV})$ & $-19 \pm 1$ & -17 & $27 \pm 1$ \\
\hline \multicolumn{4}{|c|}{$50 \mu \mathrm{g} / \mathrm{mL}$ NPs in cell medium } \\
\hline$D_{\mathrm{H}}(\mathrm{nm})$ & $283 \pm 36$ & $224 \pm 14$ & $144 \pm 2$ \\
\hline$\zeta(\mathrm{mV})$ & -13 & -23 & 6 \\
\hline \multicolumn{4}{|c|}{$200 \mu \mathrm{g} / \mathrm{mL}$ NPs in cell medium } \\
\hline$D_{\mathrm{H}}(\mathrm{n} \mathrm{m})$ & $357 \pm 8$ & $338 \pm 23$ & $137 \pm 1$ \\
\hline$\zeta(\mathrm{mV})$ & -31 & -21 & 36 \\
\hline
\end{tabular}

reduction of tetrazolium by mitochondrial dehydrogenase. Our results showed that ZnO NPs induced a strong decrease in cell viability as shown in Fig. 2b. As a matter of fact, at a concentration of $12.5 \mu \mathrm{g} / \mathrm{mL}$ of $\mathrm{ZnO}$ NPs, only $54 \%$ of cells remained metabolically active, while a complete cytotoxicity was observed up to $25 \mu \mathrm{g} / \mathrm{mL}$. A decrease in the viability of cells exposed to $\mathrm{ZnFe}_{2} \mathrm{O}_{4} \mathrm{NPs}$ was also observed. Indeed, after exposure of NR8383 to 50 and $200 \mu \mathrm{g} / \mathrm{mL}$ of $\mathrm{ZnFe}_{2} \mathrm{O}_{4} \mathrm{NPs}$, there remained $64 \%$ and $10 \%$ of metabolic active cells, respectively. NR8383 cell viability was not affected by $\mathrm{Fe}_{2} \mathrm{O}_{3}$ NPs up to a concentration of $25 \mu \mathrm{g} / \mathrm{mL}$ but decreased continuously in a dose-dependent manner (Fig. 2b). However, $\mathrm{Fe}_{2} \mathrm{O}_{3}$ NPs seemed to be less cytotoxic in our model compared with the two other NPs. Indeed, NR8383 cell viability decreased only to $30 \%$ in the presence of the highest $\mathrm{Fe}_{2} \mathrm{O}_{3}$ NPs $(200 \mu \mathrm{g} / \mathrm{mL})$ used in our study (Fig. 2b). Both in LDH and WST-1 assays were results concordant, demonstrating that the presence of $\mathrm{Zn}$ in NPs is the main factor of main toxicity (Fig. 2a).

Based on the WST-1 assay data, the calculated $\mathrm{IC}_{50}$ was 16,68 , and $>200 \mu \mathrm{g} / \mathrm{mL}$ for respectively $\mathrm{ZnO}, \mathrm{ZnFe}_{2} \mathrm{O}_{4}$, and $\mathrm{Fe}_{2} \mathrm{O}_{3} \mathrm{NPs}$, allowing us to set 
a

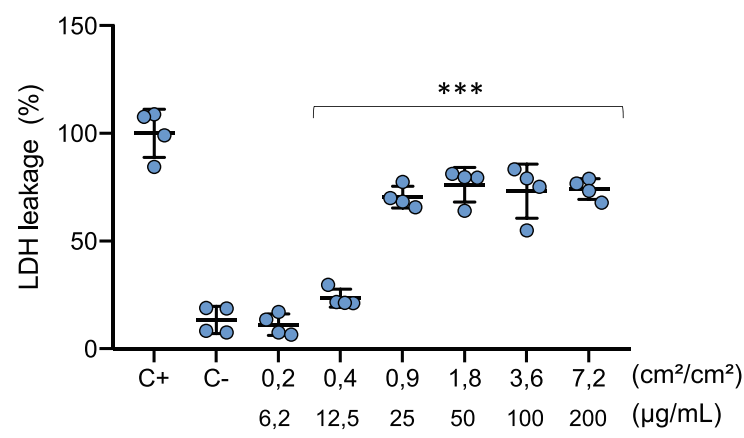

$\mathrm{ZnO}$

b

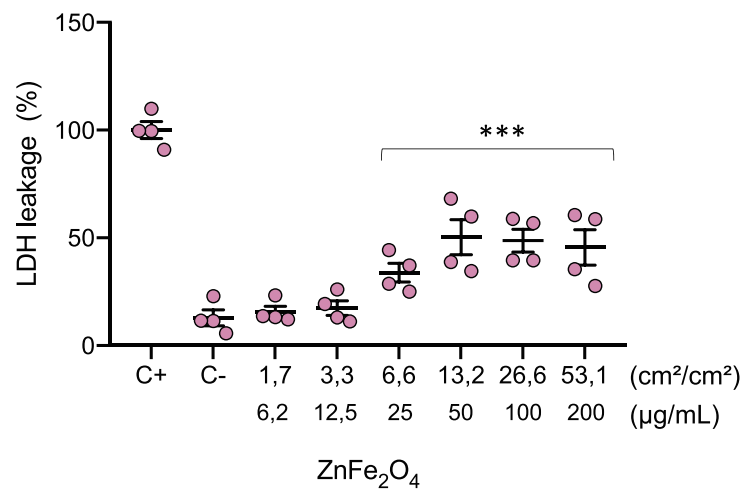

C

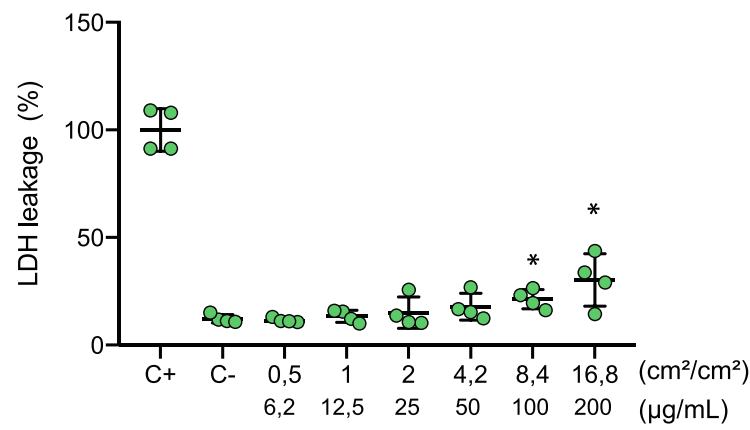

$\mathrm{Fe}_{2} \mathrm{O}_{3}$

Fig. 2 Cytotoxicity of $\mathrm{ZnO} N \mathrm{NP}(\mathbf{a}), \mathrm{ZnFe}_{2} \mathrm{O}_{4}(\mathbf{b})$, and $\mathrm{Fe}_{2} \mathrm{O}_{3}$ (c). Cytotoxicity was determined after $24 \mathrm{~h}$ exposure of NR8383 to the panel of studied nanoparticles. At the left, the induction of membrane damage after cell exposure to different studied nanoparticles by measuring the level of extracellular LDH. At the right, action of

up the optimal sub-toxic concentrations for each NP for the following experiments.

Effective dosimetry for nano-bio interactions

Based on the dose-response toxicity results for NR8383 cells exposed to $\mathrm{ZnO}, \mathrm{ZnFe}_{2} \mathrm{O}_{4}$, and $\mathrm{Fe}_{2} \mathrm{O}_{3}$, we
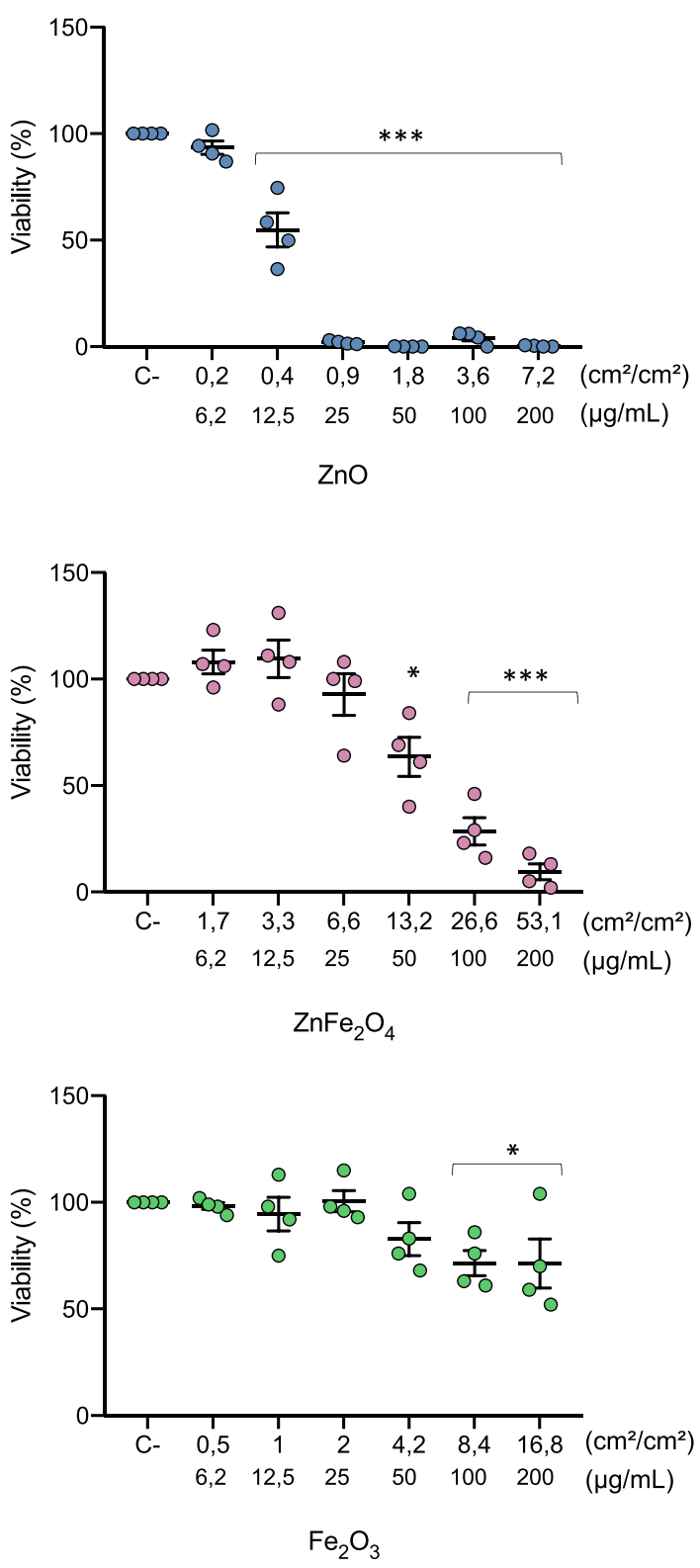

$\mathrm{ZnO}, \mathrm{ZnFe}_{2} \mathrm{O}_{4}$, and $\mathrm{Fe}_{2} \mathrm{O}_{3}$ on NR8383 metabolic activity measured by WST1 assay. Calculated $\mathrm{IC}_{50}$, based on WST-1 assay data, for $\mathrm{ZnO}, \mathrm{ZnFe}_{2} \mathrm{O}_{4}$, and $\mathrm{Fe}_{2} \mathrm{O}_{3}$ were respectively 16,68 , and more than $200 \mu \mathrm{g} / \mathrm{mL}$

deliberately decided to deepen our study with NP whose $\mathrm{IC}_{50}$ were measurable, namely $\mathrm{ZnO}$ and $\mathrm{ZnFe}_{2} \mathrm{O}_{4} \mathrm{NPs}$. Therefore, we evaluated the amount of cytotoxic NPs in contact with the cells by measuring the zinc $(\mathrm{Zn})$ and iron $(\mathrm{Fe})$ contents in the cell layers by ICP-OES. This measurement was carried out on NR8383 cells exposed for $24 \mathrm{~h}$ to both $1 / 4 \mathrm{IC}_{50}(4$ and $17 \mu \mathrm{g} / \mathrm{mL})$ and $\mathrm{IC}_{50}(16$ 
and $68 \mu \mathrm{g} / \mathrm{mL}$ ) of $\mathrm{ZnO}$ and $\mathrm{ZnFe}_{2} \mathrm{O}_{4}$, respectively. Table 3 indicates that $\mathrm{Zn}$ concentrations in/onto NR8383-cell were respectively $62.1 \pm 1.5$ and $130.7 \pm$ $0.4 \mathrm{ng} / \mathrm{mL}$, for ${ }^{1 / 4} \mathrm{IC}_{50}$ and $\mathrm{IC}_{50}$ of $\mathrm{ZnO}$. For $\mathrm{ZnFe}_{2} \mathrm{O}_{4}$ NPs, $\mathrm{Zn}$ concentrations in/onto cells were $16.1 \pm 0.3$ and $18.2 \pm 0.1 \mathrm{ng} / \mathrm{mL}$, for $1 / 4 \mathrm{IC}_{50}$ and $\mathrm{IC}_{50}$ of $\mathrm{ZnFe}_{2} \mathrm{O}_{4}$, respectively. Also, Fe concentrations were $82.7 \pm 0.2$ and $78.2 \pm 0.3 \mathrm{ng} / \mathrm{mL}$ for $1 / 4 \mathrm{IC}_{50}$ and $\mathrm{IC}_{50}$ of $\mathrm{ZnFe}_{2} \mathrm{O}_{4}$, respectively. The results showed that free $\mathrm{Zn}$ in contact with cells was more abundant following exposure to $\mathrm{ZnO} \mathrm{NPs}$ than the exposure to $\mathrm{ZnFe}_{2} \mathrm{O}_{4} \mathrm{NPs}$, conferring the primary role of free $\mathrm{Zn}$ in cell viability.

\section{Action on transcriptome}

To identify key pathways linked to the response of NR8383 to sub-toxic doses of NP exposure, transcriptomics experiments were conducted by their exposure to $\mathrm{ZnO}$ and $\mathrm{ZnFe}_{2} \mathrm{O}_{4}$ at $1 / 4 \mathrm{IC}_{50}$ dose for $4 \mathrm{~h}$. Results showed 985 and 1209 DEG that were revealed after the exposure to $\mathrm{ZnO}$ and $\mathrm{ZnFe}_{2} \mathrm{O}_{4} \mathrm{NPs}$, respectively (Fig. 3a).

Following exposure to $\mathrm{ZnO}$, the proportion of downregulated genes was 100 and upregulated genes was 885. Interestingly, exposure to $\mathrm{ZnFe}_{2} \mathrm{O}_{4}$ led to a higher fraction of downregulated genes, e.g., 1191 versus only 18 upregulated genes (Fig. 3a). Our results highlighted 118 common DEG to both exposure conditions, whereas 867 DEG were specific to $\mathrm{ZnO}$ and 1091 DEG were specific to $\mathrm{ZnFe}_{2} \mathrm{O}_{4}$ (Fig. 3b). To determine the main affected pathways, all DEG were further analyzed using IPA® software. The heatmap (Fig. 4) showed 14 deregulated canonical pathways of which were activated. Indeed, eIF2 and both eIF4/p70S6K and mTOR signaling pathways were predicted to be activated in cells exposed to $\mathrm{ZnO}$ but not following exposure to $\mathrm{ZnFe}_{2} \mathrm{O}_{4}$. On the contrary, eIF2, both eIF4/p70S6K,
PDGF, and integrin signaling were predicted to be inhibited in cells exposed to $\mathrm{ZnFe}_{2} \mathrm{O}_{4}$.

Finally, the most significant deregulated common pathways in $1 / 4 \mathrm{IC}_{50}$ exposure to $\mathrm{ZnO}$ and $\mathrm{ZnFe}_{2} \mathrm{O}_{4} \mathrm{NP}$ were those involved in the homeostasis of cellular protein production/degradation. What differs is the predictive trend of activation or inhibition of these pathways calculated by IPA.

To go further and to delineate a potential gene signature, we focused on the most up- and most downregulated genes in NR8383 exposed to $\mathrm{ZnO}$ NPs (Fig. 5a) and $\mathrm{ZnFe}_{2} \mathrm{O}_{4}$ NPs (Fig. 5b). Not surprisingly, Mt1a and $M t 2 A$, both metallothioneins involved in metal homeostasis, were among the most upregulated genes in both conditions (FC respectively +28 and +130 for $\mathrm{ZnO}$; FC respectively +7 and +78 , for $\left.\mathrm{ZnFe}_{2} \mathrm{O}_{4}\right)$. Slc30al $(\mathrm{FC}+4)$ and $W d r 45(\mathrm{FC}+5)$ also involved in metal homeostasis were also highly upregulated, but only after exposure to $\mathrm{ZnO}$ or to $\mathrm{ZnFe}_{2} \mathrm{O}_{4}$, respectively. $\mathrm{ZnO}$ specific gene signature further englobed the overexpression of Pla2g16 (FC +7) a membrane damage sensor; S100a4 $(\mathrm{FC}+7)$ involved in macrophage-induced lung fibrosis ( $\mathrm{Li}$ et al. 2018; Zhang et al. 2018); Rps14 (FC +6), Rps27 (FC + 5), and Mrps15 (FC + 5), three protein synthesis regulators. Besides, $\mathrm{ZnO}$ exposure signature was also characterized by a downregulation of Tp53inp (FC - 31); a stress response mediator, Slfn3 (FC -23), Akap9 (FC - 16), and Rockl (FC - 24), three cell cycle/cytoskeleton regulators; and Zeb2 (FC -14), Smarca5 (FC -6), Smarcad1 (FC - 11), and Med13 (FC - 10), four transcriptional regulators. NR8383 cell specific gene signature following exposure to a sub-lethal dose of $\mathrm{ZnFe}_{2} \mathrm{O}_{4}$ was marked by the deregulation of genes involved in protein synthesis such as Eefla2 $(\mathrm{FC}+2), \operatorname{Atf3}(\mathrm{FC}+6)$, Cyp4a8 $(\mathrm{FC}-$ 45), and Rpl1 (FC - 34), as well as both zinc-finger proteins Zfand2a $(\mathrm{FC}+12)$ and Znrf4 $(\mathrm{FC}+7)$, in

Table 3 Measure of zinc $(\mathrm{Zn})$ and iron $(\mathrm{Fe})$ in/onto NR8383 cells by inductively coupled plasma-optical emission spectrometer

\begin{tabular}{|c|c|c|c|c|}
\hline & \multicolumn{2}{|l|}{$\mathrm{ZnO}$} & \multicolumn{2}{|l|}{$\mathrm{ZnFe}_{2} \mathrm{O}_{4}$} \\
\hline & $1 / 4 \mathrm{IC}_{50}$ & $\mathrm{IC}_{50}$ & $1 / 4 \mathrm{IC}_{50}$ & $\mathrm{IC}_{50}$ \\
\hline Theoretical NP concentration $(\mu \mathrm{g} / \mathrm{mL})$ & 4 & 16 & 17 & 68 \\
\hline Measured $\mathrm{Zn}$ concentration $(\mathrm{ng} / \mathrm{mL})$ in cell phase & $62.1 \pm 1.5$ & $130.7 \pm 0.4$ & $16.1 \pm 0.3$ & $18.2 \mathrm{v} 0.1$ \\
\hline Measured Fe concentration $(\mathrm{ng} / \mathrm{mL})$ in cell phase & n.d & n.d & $82.7 \pm 0.2$ & $78.2 \pm 0.3$ \\
\hline
\end{tabular}


a
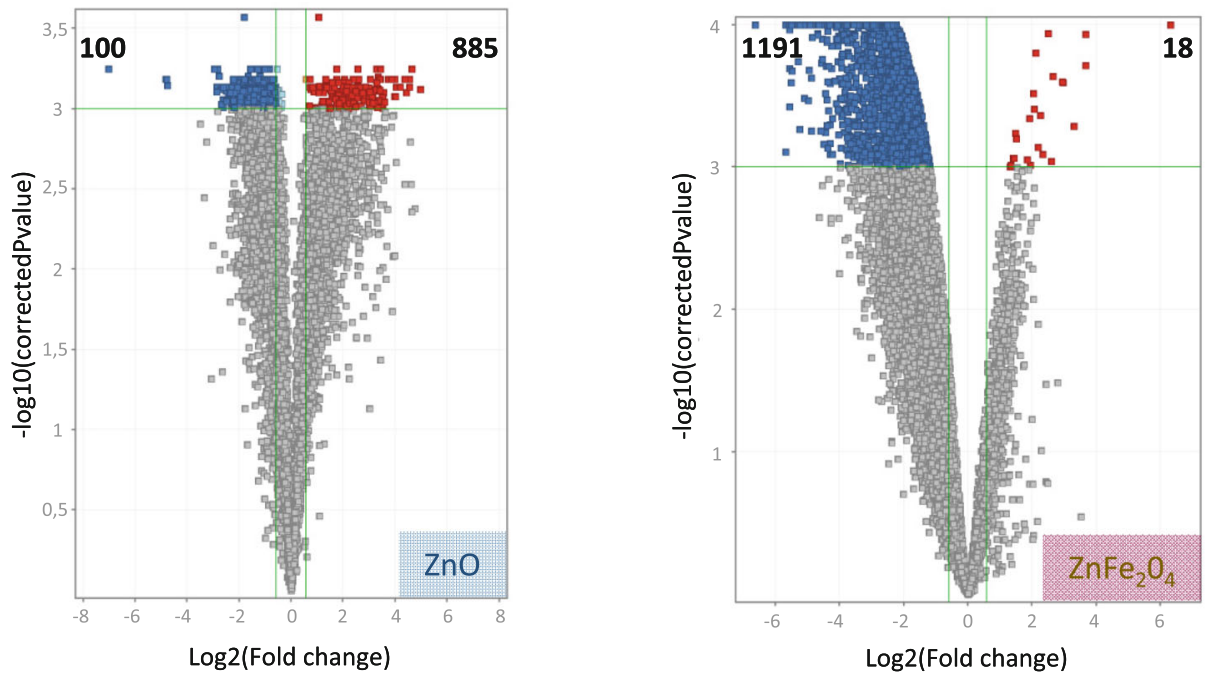

Failed to pass both of the cut-offs

Passed both cut-offs and up-regulated

Passed both cut-offs and down-regulated

b

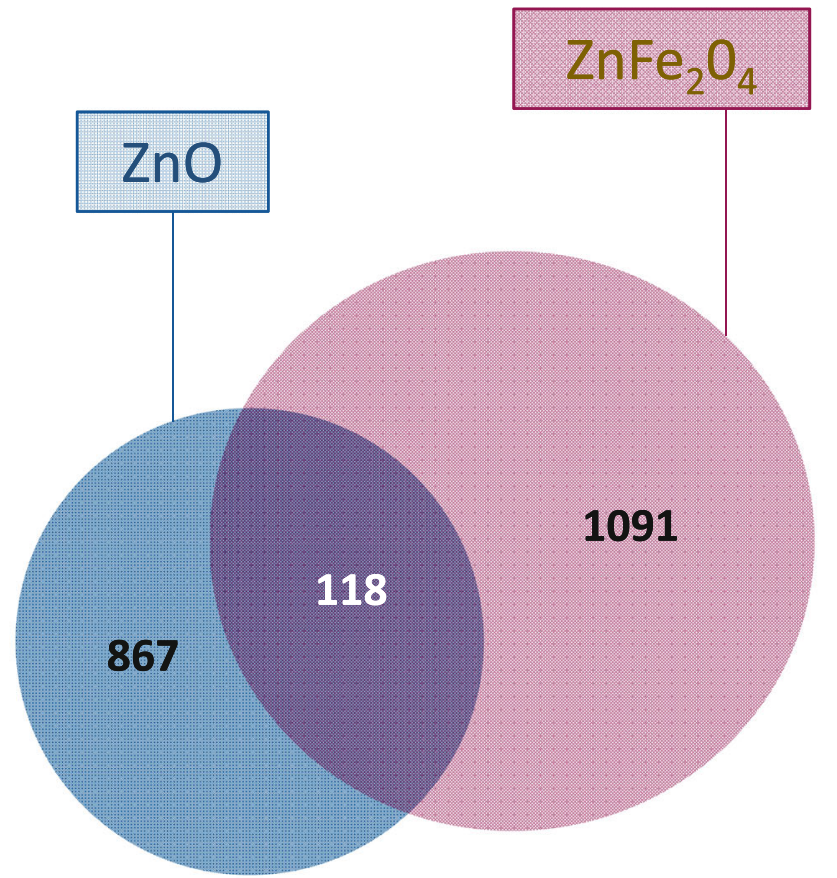

Fig. 3 Differentially expressed genes (DEG) of NR8383 cells exposed to $1 / 4 \mathrm{IC}_{50}$ of $\mathrm{ZnO}$ and $\mathrm{ZnFe}_{2} \mathrm{O}_{3}$ NPs during $4 \mathrm{~h}$. Two cutoffs were applied: statistical test Benjamini-Hochberg corrected at $p$ value $<0.001$ and fold changes $>|1,5|$. a Representative volcano plots of differentially overexpressed (in red) and downexpressed (in blue) genes, for each exposure condition. Numbers of DEG are indicated. b Venn diagram showing common differential gene expression between cells exposed to $\mathrm{ZnO}$ and $\mathrm{ZnFe}_{2} \mathrm{O}_{3} \mathrm{NPs}$ membrane damage sensing, such as $\operatorname{Sdpr}(\mathrm{FC}-46)$, and in cell cycle/cytoskeleton regulation such as
Mki67 (FC - 23) and Sntal (FC - 30). Genes encoded for transcriptional regulators, such as Smarca5 (FC - 


\section{Enrichment score}

$-5$

6

No activity pattern available

Non differentially expressed

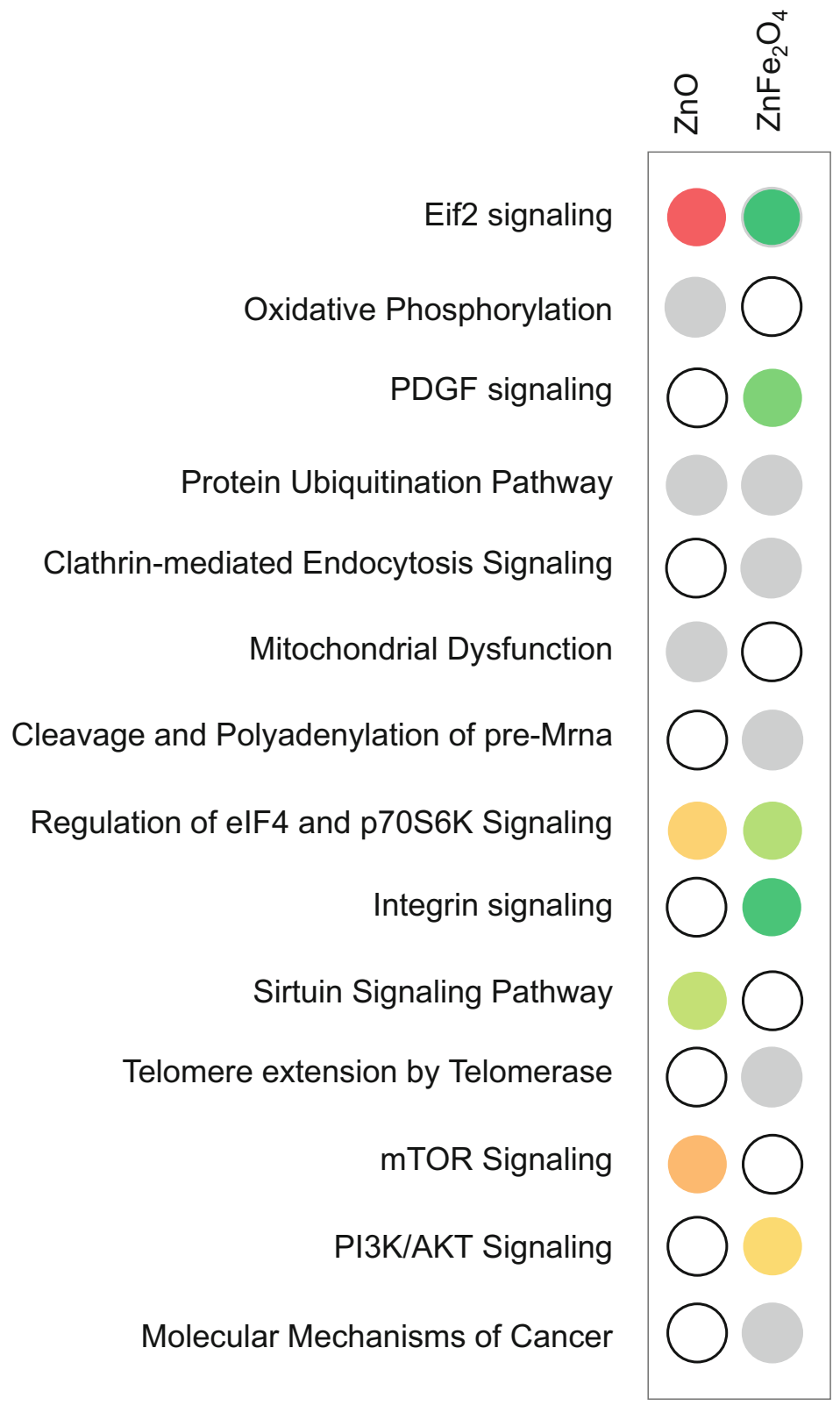

Fig. 4 Heatmap showing 14 deregulated canonical pathways after $\mathrm{ZnO}$ and $\mathrm{ZnFe}_{2} \mathrm{O}_{4} \mathrm{NP}$ exposures. Statistical test Benjamini-Hochberg corrected at $p$ value $<0.001$ and fold changes $=|1,5|$. IPA software based on $p<0.05$. Deregulated pathway more significant from left to right

12) and Hipk2 (FC - 47), and immune response effectors, such as CD68 (FC - 29), Ccl22 (FC - 29), and Gdf15 (FC + 4), were also deregulated. The exposure of NR8383 to $\mathrm{ZnFe}_{2} \mathrm{O}_{4}$ NPs further showed an overexpression of Alas1 ( FC +4) involved in heme biosynthesis (Fig. 5).
Effect on proteome

Differential protein expression from NR8383 cells exposed for $24 \mathrm{~h}$ to $1 / 4 \mathrm{IC}_{50}$ of $\mathrm{ZnO}$ and $\mathrm{ZnFe}_{2} \mathrm{O}_{4}$ NPs was further investigated by using mass spectrometry-based proteomics approach. Mass spectrometry protein 


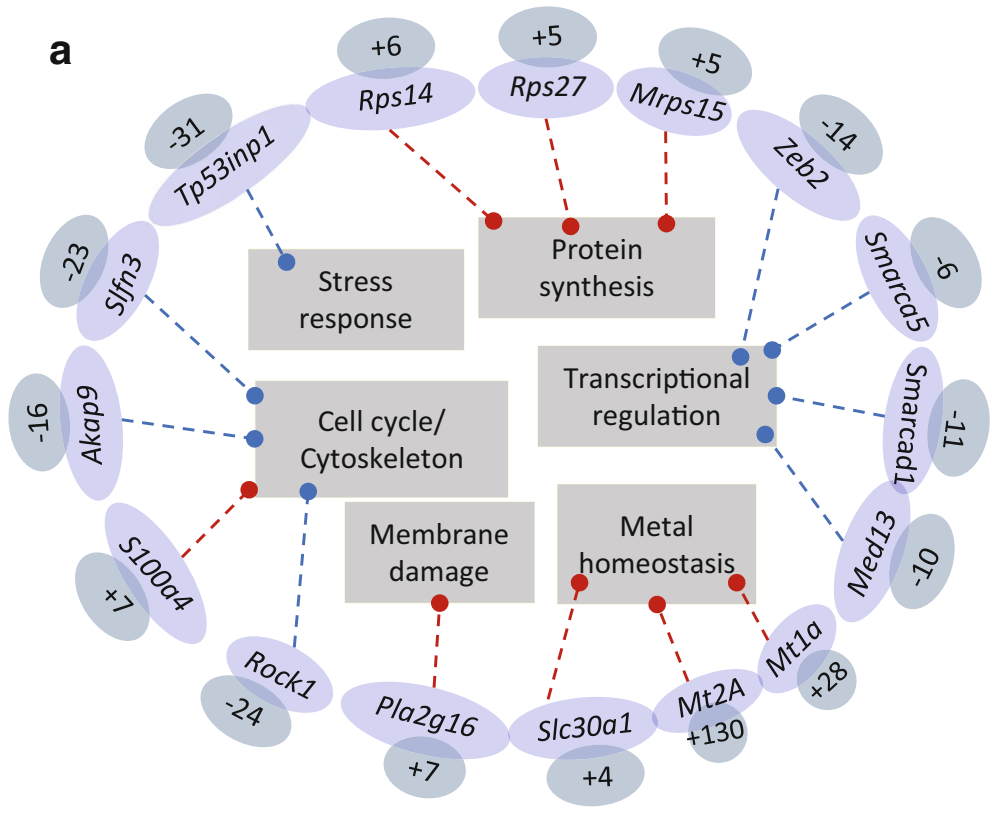

b

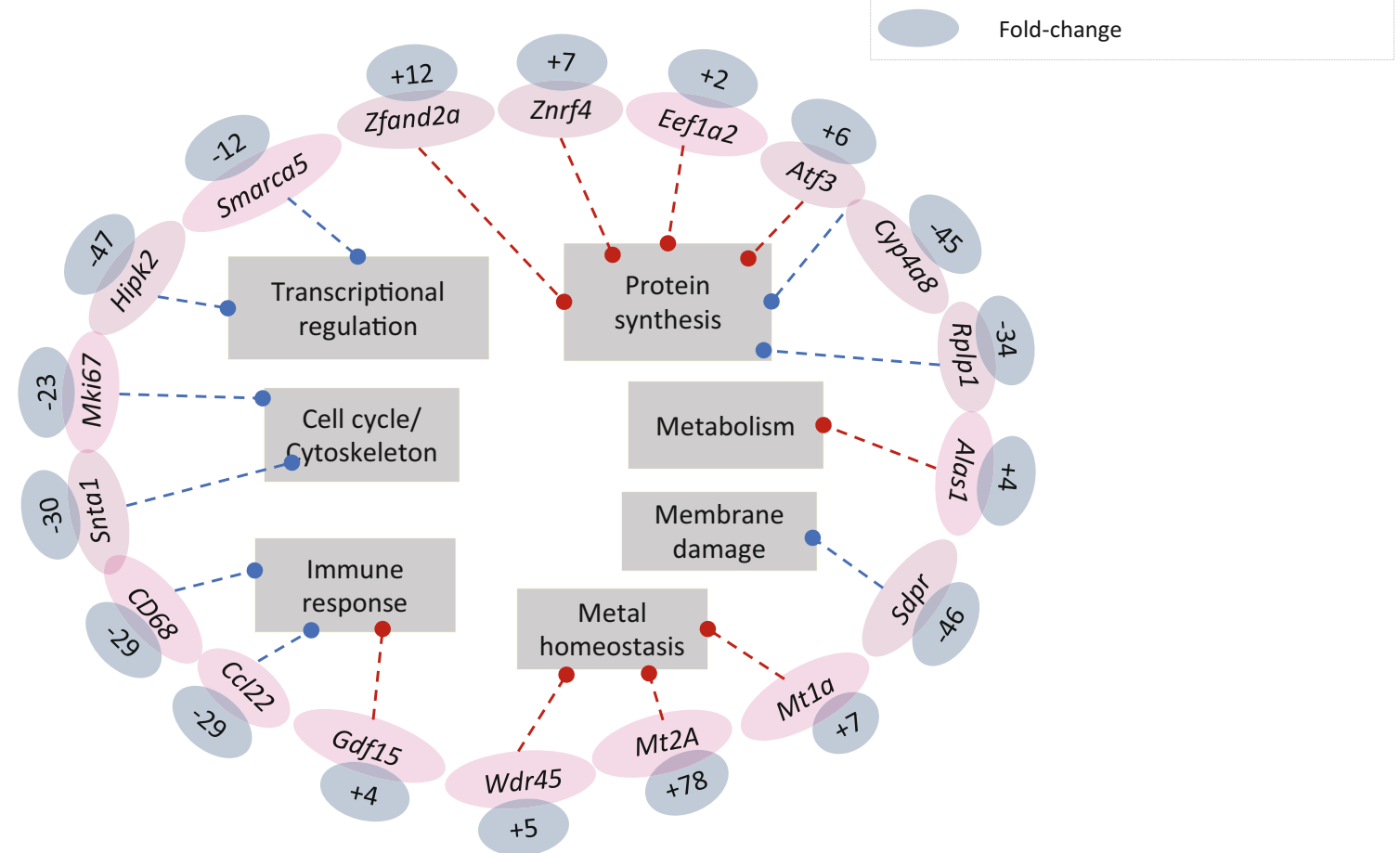

Fig. 5 The main strongly deregulated genes in NR8383 cells exposed to $1 / 4 \mathrm{IC}_{50}$ of $\mathrm{ZnO}$ NPs (a) and $1 / 4 \mathrm{IC}_{50}$ of $\mathrm{ZnFe}_{2} \mathrm{O}_{4} \mathrm{NPs}$ (b) during $4 \mathrm{~h}$. Statistical test was Benjamini-Hochberg corrected at $p$ value $<0.001$. Both blue (a) and pink (b) colors are representing the $\mathrm{ZnO}$ and $\mathrm{ZnFe}_{2} \mathrm{O}_{4} \mathrm{NP}$ deregulated genes. The

identification and quantification indicated 348 differentially expressed proteins (DEP) in exposed cells to $\mathrm{ZnO}$ compared with unexposed ones with $p$ value $<0.05$ and fold change values are in the gray circles linked to the corresponding genes. The red and blue arrows indicate overexpression and underexpression of linked genes, respectively. Finally, the functions involved are arranged in rectangles

$1.5<$ ratio $<1$ (Fig. 6). Cells exposed to $1 / 4 \mathrm{IC}_{50}$ $\mathrm{ZnFe}_{2} \mathrm{O}_{4}$ NPs showed total 795 DEP (Fig. 6). Furthermore, 211 DEP were common to both exposure 
conditions. NR8383 exposed to ZnO NPs showed 137 specific DEP while $\mathrm{ZnFe}_{2} \mathrm{O}_{4}$ NP exposure led to 584 specific DEP (Fig. 6b). Both gene and protein expressions were more abundant after $\mathrm{ZnFe}_{2} \mathrm{O}_{4}$ exposure and displayed more underexpressed elements than overexpressed ones (Figs. 3a and 6a).

To assess the molecular pathways, we also analyzed DEP by using the IPA software. Table 4 indicates the final ranking of the selected canonical pathways ( $p$ value $\leq 0.05$ ) together with the number of deregulated proteins involved for each condition, and the enrichment score for each significantly deregulated pathway. Indeed, protein synthesis with the eIF2 signaling pathway, stress response with mitochondrial dysfunction, and sirtuin signaling were the most affected functions. Indeed, 16 and 30 DEP were found to be linked to eIF2 signaling following exposure to NPs $\mathrm{ZnO}$ and $\mathrm{ZnFe}_{2} \mathrm{O}_{4}$, respectively.

Interestingly, IPA analysis revealed a trend toward activation of the eIF2 pathway following both exposures, in the protein synthesis cluster. Similarly, in the stress response cluster, 15 and 24 of DEP were linked to sirtuin signaling and 13 and 24 of DEP were ranked in mitochondrial dysfunction in cells exposed to $\mathrm{ZnO}$ and $\mathrm{ZnFe}_{2} \mathrm{O}_{4} \mathrm{NPs}$, respectively.

a

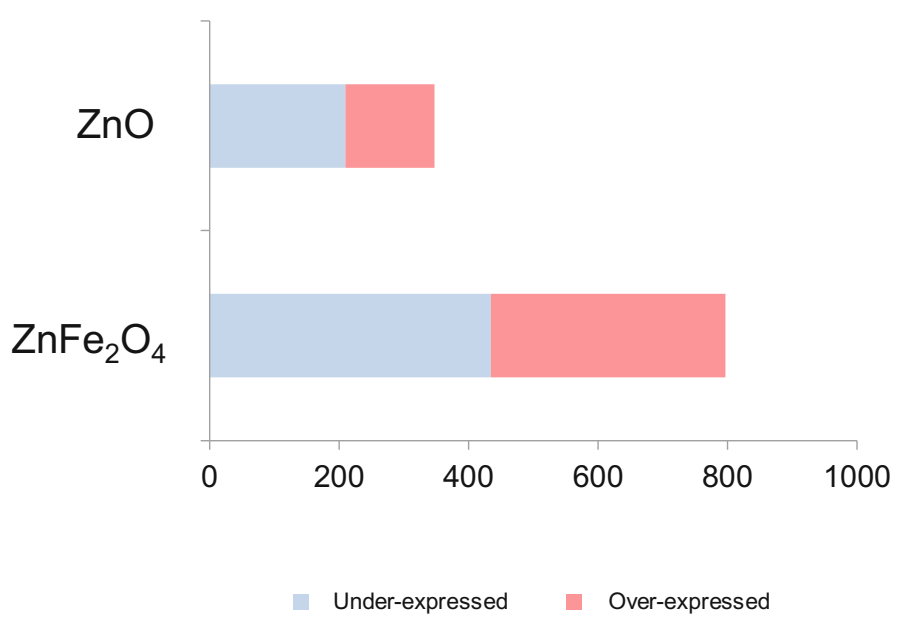

The superpathway of cholesterol biosynthesis in lipid biosynthesis cluster revealed a positive enrichment score with following exposure to ZnO NPs namely a predicted activation, as sirtuin pathway, as well as deregulation of VEGF signaling that was specific to $\mathrm{ZnO}$ exposure. On the other hand, this pathway was not suggested as activated following exposure to $\mathrm{ZnFe}_{2} \mathrm{O}_{4}$ NPs. In addition, the metal exposure response included the iron homeostasis signaling pathway which was deregulated only after exposure to $\mathrm{ZnFe}_{2} \mathrm{O}_{4} \mathrm{NPs}$, not after exposure to $\mathrm{ZnO} \mathrm{NPs}$, confirming a role of iron at an ionic level.

Moreover, the most deregulated proteins, namely 23 after $\mathrm{ZnO}$ exposure and 28 after $\mathrm{ZnFe}_{2} \mathrm{O}_{4}$ exposure, have been analyzed on STRING 10.5 version (http://string-db.org/). Overexpressed (in red) and underexpressed (in blue) proteins revealed six common clusters following $\mathrm{ZnO}$ (Fig. 7a) and $\mathrm{ZnFe}_{2} \mathrm{O}_{4}$ exposures (Fig. 7b). Those clusters were referred to as "cytoskeleton modeling" with 2 proteins that were identically deregulated after both exposures, "oxidative stress," "protein synthesis" with mainly underexpressed proteins, "immune response," and "zinc-related proteins."

Fig. 6 Histogram of proteomic data (a). Data for the total differentially produced proteins (DPP). Venn diagram (b) showing common DPP between cells exposed to $\mathrm{ZnO}$ and $\mathrm{ZnFe}_{2} \mathrm{O}_{3} \mathrm{NPs}$ 
From the list of these deregulated proteins, eight proteins were common following both exposures studied, namely Il1rap, Gpx4, Lss, Mmp9, Pum1, Rpa2, Tubg1, and Map1lc3b (circled in yellow in Fig. 7). Also, comparison of both DEP (Fig. 7) and DEG (Fig. 5) showed that Slc30a1 and Mt1a were overexpressed at transcriptional and protein levels in cells exposed to $\mathrm{ZnO}$ and $\mathrm{ZnFe}_{2} \mathrm{O}_{4} \mathrm{NPs}$, respectively.

\section{Discussion}

The cellular response to exposure to sub-toxic doses of nanoparticles of metal oxides has been investigated using a rat alveolar pulmonary NR8383 macrophage model. The aim was to decipher transcriptional and proteomic signatures in cells.

Cell viability analyses following exposure of NR8383 macrophages to increasing doses of $\mathrm{ZnO}$, $\mathrm{ZnFe}_{2} \mathrm{O}_{4}$, and $\mathrm{Fe}_{2} \mathrm{O}_{3}$ clearly highlight the higher cytotoxic potential of $\mathrm{ZnO}$, followed by $\mathrm{ZnFe}_{2} \mathrm{O}_{4}$ and thereafter $\mathrm{Fe}_{2} \mathrm{O}_{3}$.

Physicochemical properties of NPs, especially size and specific surface area, have been reported to affect cell viability. Indeed, nanoscaled particles are known to be significantly more toxic than microscaled particles (Li et al. 2018; Zhang et al. 2018). Here, in our experimental conditions, we showed that $\mathrm{ZnO}$ NPs display the larger primary size and the lower specific area, suggesting that $\mathrm{ZnO}$ toxicity in this model could be attributed to other properties such as their solubility, morphology, or presence of Zn. Our data are in agreement with the reported toxicity of $\mathrm{ZnO}$ in rat epithelial and pulmonary cell models as well as in in PMAdifferentiated THP-1 monocytic cells to a macrophagelike phenotype (Safar et al. 2018; Wiemann et al. 2016). Moreover, the $\mathrm{ZnO}$ NPs toxicity potential seems to be cell-type dependent as similar concentrations of $\mathrm{ZnO}$ NPs do not lead to any cytotoxicity in exposed human monocyte THP1 cells and in human umbilical vein endothelial cells (Chen et al. 2017; Gong et al. 2017). However, this cell-type-dependent toxicity of $\mathrm{ZnO}$ needs to be confirmed on a larger panel of cells and tissues. This would be a unique opportunity to better define the mechanism of adverse health effects on exposure to $\mathrm{ZnO}$. In our model, $\mathrm{Fe}_{2} \mathrm{O}_{3}$ NPs affect NR8383 macrophages' viability only at the highest dose used $(200 \mu \mathrm{g} / \mathrm{mL})$, supporting the anterior finding that $\mathrm{Fe}_{2} \mathrm{O}_{3}$ is rather a "passive" NPs (Wiemann et al.
2016). Besides, $\mathrm{ZnFe}_{2} \mathrm{O}_{4}$ NPs demonstrate an intermediate dose-dependent effect on NR8383 cells, between those of $\mathrm{ZnO}$ and $\mathrm{Fe}_{2} \mathrm{O}_{3}$ NPs. As $\mathrm{ZnFe}_{2} \mathrm{O}_{4}$ NPs are composed of 5-10 wt\% of $\mathrm{ZnO}$ and $10-15 \mathrm{wt} \%$ $\mathrm{Fe}_{2} \mathrm{O}_{3}$, we could postulate that $\mathrm{ZnFe}_{2} \mathrm{O}_{4}$ toxicity relies mainly on the toxic potential of $\mathrm{ZnO}$. As (i) WST-1 may be reduced by NADPH oxidases and (ii) $\mathrm{ZnO}$ may activate superoxide formation by triggering $\mathrm{p} 47 \mathrm{phox}$, we assayed cell viability using resazurin reduction (Alamar blue ${ }^{\mathrm{TM}}$ ), that is reduced by the first enzyme of the mitochondrial respiratory chain, NADPH dehydrogenase. Fifty percent of the latter enzyme which occurred with $5.5 \mu \mathrm{g} / \mathrm{mL}$ of $\mathrm{ZnO}$ correspond to $16.0 \mu \mathrm{g} /$ $\mathrm{mL}$ for succinate dehydrogenase (data not shown). One can reasonably assume that the $\mathrm{IC}_{50}$ of cell viability is comprised between both values. Furthermore, when $\mathrm{IC}_{50}$ of viability is taken into account, the average of $\mathrm{IC}_{50 \%}$ was $10.8 \pm 5.23 \mu \mathrm{g} / \mathrm{mL}$. For $\mathrm{ZnFe}_{2} \mathrm{O}_{4}, \mathrm{IC}_{50}$ were $98.0,58$, and 68 when respectively calculated with Spearman and Karber method of resofurin, LDH, and tetrazolium salts. The calculated average was $74.7 \pm$ $20.9 \mu \mathrm{g} / \mathrm{mL}$ which was statistically different at $p<$ 0.05 of the average of $\mathrm{ZnO}$, demonstrating higher in vitro toxicity of the latter NPs.

Following exposure to sub-toxic concentrations of NPs $\left(1 / 4 \mathrm{IC}_{50}\right)$, molecular pathways are supposed to produce an adaptive response in order to maintain the cellular homeostasis in front of the induced disturbances and may confer a resistance or an adaptation following the aggression of the toxic (Jennings 2013). Therefore, the pathways of both toxicity and adaptive responses are important to explore, in order to understand the exact cellular reaction to NPs exposure. So, we realized a transcriptome and a proteome exploration after $4 \mathrm{~h}$ and $24 \mathrm{~h}$ of exposure of $\mathrm{NR} 8383$ cells to the $1 / 4 \mathrm{IC}_{50}$ of $\mathrm{ZnO}$ and $\mathrm{ZnFe}_{2} \mathrm{O}_{4} \mathrm{NPs}$, respectively. As far as we know, this is the first transcriptome and proteome study for $\mathrm{ZnFe}_{2} \mathrm{O}_{4}$ NPs reported.

One of the aims of the work was to decipher key molecular pathways and/or functions associated with NR8383 cell response to sub-toxic doses of $\mathrm{ZnO}$ and $\mathrm{ZnFe}_{2} \mathrm{O}_{4} \mathrm{NPs}$. Therefore, the most deregulated genes were involved in metal homeostasis. Indeed, the metallothioneins Mt1a and Mt2a were commonly overexpressed at the transcriptional level. Exposure to $\mathrm{ZnO}$ and $\mathrm{ZnFe}_{2} \mathrm{O}_{4}$ NPs leads also to specific deregulation of other effectors involved in metal homeostasis. Indeed, Slc30al and $W d r 45$ were respectively increased following exposure to $\mathrm{ZnO}$ and $\mathrm{ZnFe}_{2} \mathrm{O}_{4}$ NPs. Noteworthy is the 
Table 4 Ranking of selected canonical pathways and number of deregulated produced proteins involved in each condition

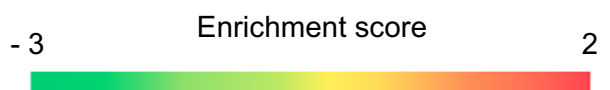

2

\begin{tabular}{|c|c|c|c|c|c|c|c|}
\hline & & \multicolumn{3}{|c|}{$\begin{array}{l}\text { No activity pattern } \\
\text { available }\end{array}$} & \multicolumn{3}{|c|}{$\begin{array}{l}\text { Non differentially } \\
\text { expressed }\end{array}$} \\
\hline \multicolumn{2}{|r|}{ Response } & \multicolumn{2}{|c|}{$\begin{array}{c}\text { Ranking of } \\
\text { canonical } \\
\text { pathways }\end{array}$} & \multicolumn{2}{|c|}{$\begin{array}{c}\text { Number of } \\
\text { deregulated } \\
\text { proteins }\end{array}$} & \multicolumn{2}{|c|}{$\begin{array}{c}\text { Enrichment } \\
\text { score }\end{array}$} \\
\hline $\begin{array}{l}\text { Functional } \\
\text { categories }\end{array}$ & Canonical pathways & $\stackrel{\circ}{N}$ & 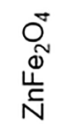 & $\frac{0}{N}$ & 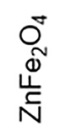 & $\stackrel{0}{\text { N }}$ & 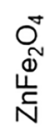 \\
\hline \multirow[t]{5}{*}{ Stress response } & - Mitochondrial dysfunction & 2 & 3 & 13 & 24 & & \\
\hline & - Oxidative phosphorylation & 8 & 59 & 8 & 10 & & \\
\hline & - $\quad$ mTOR signaling & 49 & 8 & 9 & 22 & & \\
\hline & - NRF2-mediated oxidative stress response & 24 & 6 & 10 & 24 & & \\
\hline & - Sirtuin signaling & 5 & 4 & 15 & 24 & & \\
\hline \multirow{2}{*}{$\begin{array}{l}\text { Cell cycle/ } \\
\text { proliferation }\end{array}$} & - PI3KJAKT signalling & 45 & 9 & 7 & 16 & & \\
\hline & - VEGF signaling & 12 & - & 8 & - & & \\
\hline \multirow{4}{*}{$\begin{array}{l}\text { Protein synthesis/ } \\
\text { modification }\end{array}$} & - EIF2 signaling & 1 & 1 & 16 & 30 & & \\
\hline & - Regulation of elF4 and P70S6K signaling & 7 & 2 & 10 & 24 & & \\
\hline & - Protein ubiquitination pathway & 39 & 5 & 11 & 26 & & \\
\hline & - Unfolded protein response & 3 & 30 & 7 & 8 & & \\
\hline \multirow[t]{2}{*}{ Cell mobility } & - Paxillin signaling & 5 & 39 & 9 & 12 & & \\
\hline & - Integrin signaling & 8 & 16 & 12 & 21 & & \\
\hline Lipid homeostasis & - Superpathway of cholesterol biosynthesis & 9 & 88 & 4 & 3 & & \\
\hline Cell modelling & - Actin cytoskeleton signaling & 46 & 7 & 10 & 24 & & \\
\hline Cancer & - Cancer drug resistance by drug efflux & 9 & 109 & 6 & 6 & & \\
\hline $\begin{array}{l}\text { Metal exposure } \\
\text { response }\end{array}$ & - Iron homeostasis signaling pathway & - & 12 & - & 16 & & \\
\hline
\end{tabular}

upregulation of $\mathrm{Zn}$ transporter Slc30alafter exposure to $\mathrm{Zn}$ element which has already been observed following an in vivo exposure of $\mathrm{Zn}$ to piglets (Chai et al. 2014). Moreover, the higher amount of $\mathrm{Zn}$ element found in cells exposed to $\mathrm{ZnO}$ NPs, in addition to their soluble potential, could be related to the transient expression of $\mathrm{Zn}$-dependent proteins, such as those encoded by Slc30a genes, Zfand $2 b$, Zgpat, Zfp637, or Zfyve19 (Table S1a and S1b).

A metal exposure response was also evidenced following the analysis of proteomic data with IPA ${ }^{\mathrm{TM}}$ software;
Mmp9 was highly downregulated for both studied exposures (Fig. 7). The iron homeostasis signaling pathway was only deregulated after exposure to $\mathrm{ZnFe}_{2} \mathrm{O}_{4}$ (Table 4). Our results are in agreement with those of Tuomela et al. (2013) who demonstrated an overexpression of different metallothioneins as a gene signature of three different immune cell lines after the exposure to $\mathrm{ZnO}$ NPs. Other recent studies revealed as well the expression of MTs after exposure to $\mathrm{Zn}$, nano- $\mathrm{ZnO}$, or micro- $\mathrm{ZnO}$ (Chai et al. 2014; Safar et al. 2018; Yang et al. 2017). 
a

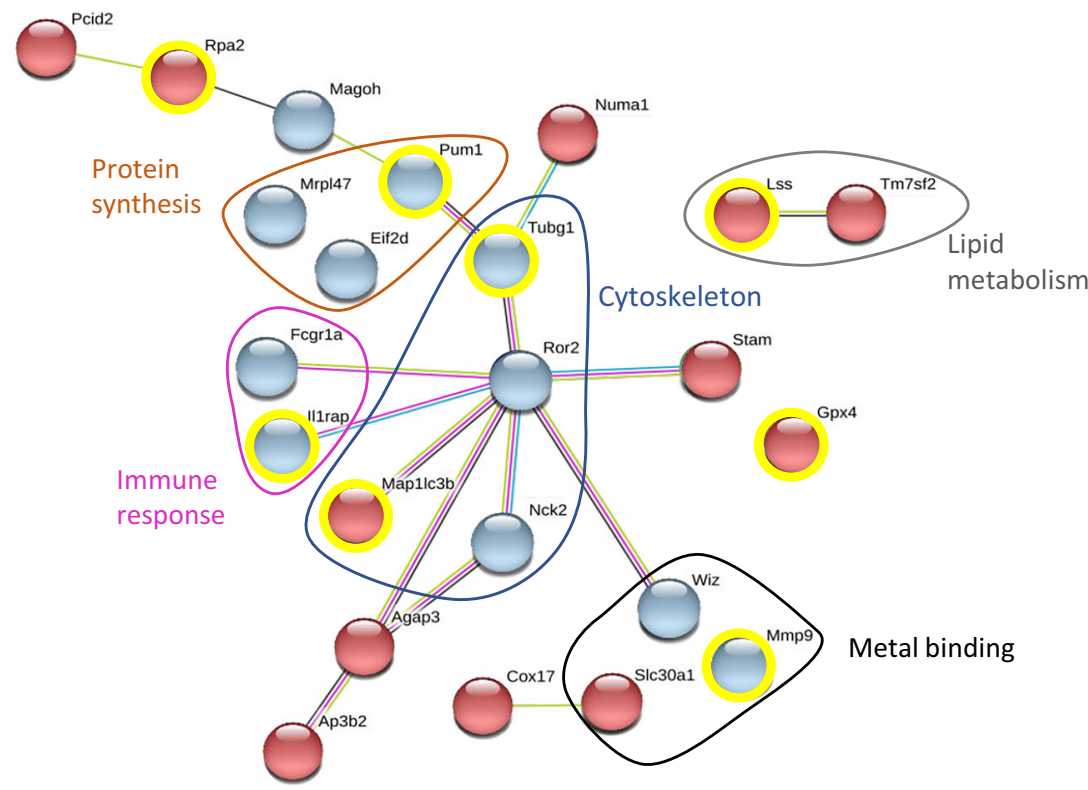

b

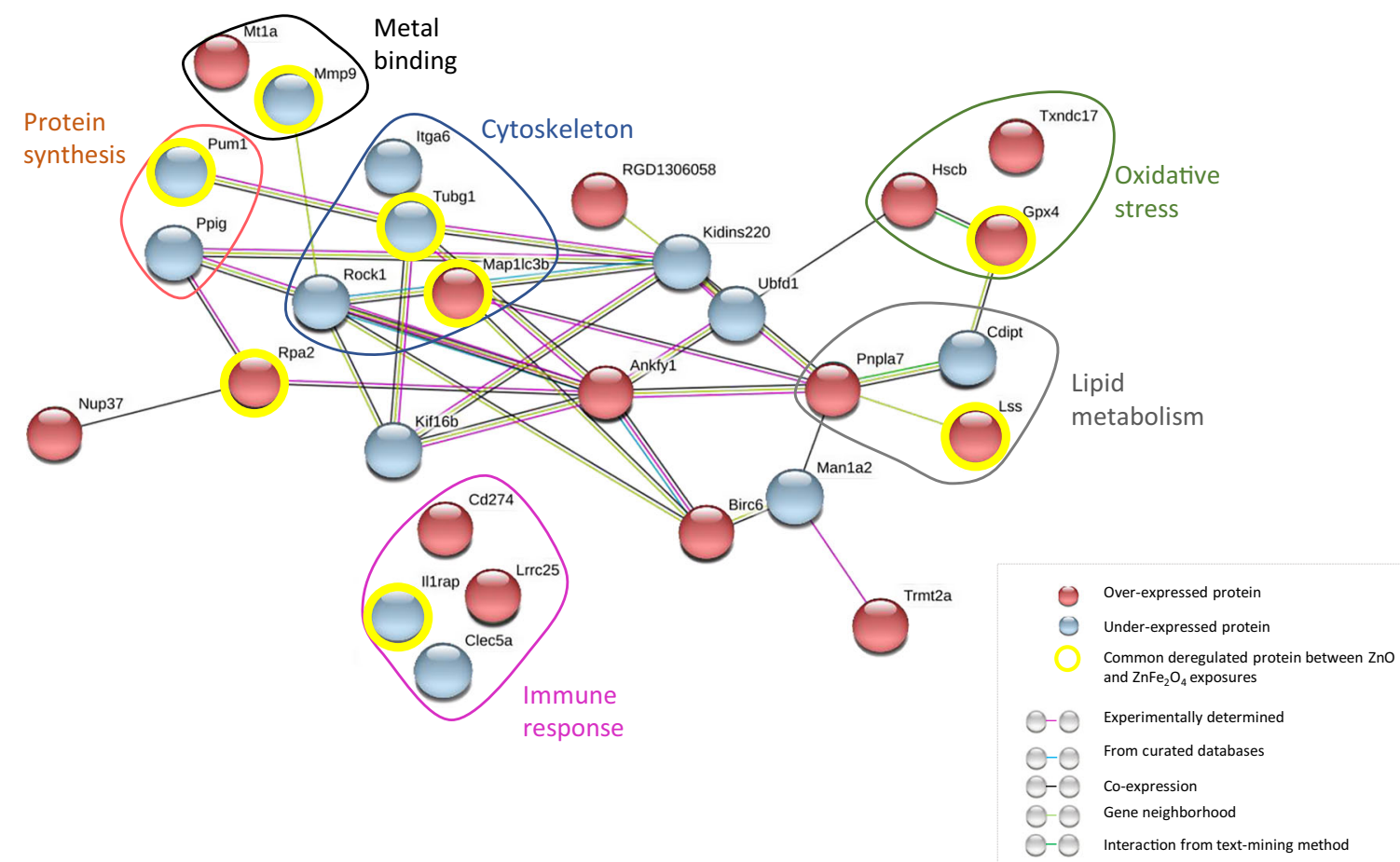

Fig. 7 The main strongly deregulated proteins in NR8383 cells exposed to both $1 / 4 \mathrm{IC}_{50}$ doses of $\mathrm{ZnO} N P s(\mathbf{a})$ and $\mathrm{ZnFe}_{2} \mathrm{O}_{4} \mathrm{NPs}(\mathbf{b})$ during 24 h. Proteins ratio (a): $16 \times 10^{6} \leq \mathrm{R}_{\mathrm{ZnO}} \leq 0.18$; protein ratio (b) $6 \times 10^{6} \leq \mathrm{R}_{\mathrm{ZnFe} 2 \mathrm{O} 4} \leq 2.6 \times 10^{-7}$

The overexpression of metallothioneins is an indicator of an adaptive response that plays a role in defense mechanisms against oxidative stress. Indeed, they are known to efficiently trap oxygen species (ROS) as well as Zn ions (Vallee 1995; Sato and Kondoh 2002; Vašák
2005; Lindeque et al. 2010). In this study, metallothioneins were not the only indicator of oxidative stress. After $24 \mathrm{~h}$ of exposure to NPs $\mathrm{ZnO}$ and $\mathrm{ZnFe}_{2} \mathrm{O}_{4}$, deregulated proteins were mainly involved in mitochondrial dysfunction, oxidative 
phosphorylation, and sirtuin pathways. Our data are in agreement with previous studies (Aude-Garcia et al. 2016; Chevallet et al. 2016; George and Ahmad 2016; Niska et al. 2015). Altogether, these findings suggest that the regulation of these pathways might help cells capture and fix $\mathrm{Zn}^{2+}$ and reduce the oxidative effect induced by $\mathrm{ZnO}$ and $\mathrm{ZnFe}_{2} \mathrm{O}_{4} \mathrm{NPs}$.

One of the consequences of oxidative stress is the accumulation of cholesterol (Gesquière et al. 1999). Indeed, overexpression of proteins involved in cholesterol synthesis has been revealed in both studied exposures. At sub-toxic doses of exposure to $\mathrm{ZnO}$ and $\mathrm{ZnFe}_{2} \mathrm{O}_{4} \mathrm{NPs}$ for $24 \mathrm{~h}$, the overexpression of the $\mathrm{Gpx} 4$ protein could be a response to cholesterol synthesis. The Gpx4 enzyme has important biological functions; it is particularly known for its action against lipid peroxidation of cells and its inhibition induces cell death by ferroptosis (Maiorino et al. 2018). All these results suggest that the induction of oxidative stress would cause lipid accumulation and drop antiperoxidative capacity of the cells, which could justify the overexpression of the Gpx4 enzyme.

Moreover, cholesterol production control occurs in the endoplasmic reticulum (ER). Thus, when the mechanism of cholesterol production is altered, it induces ER stress (Sozen and Ozer 2017).

In this present study, we revealed the significant deregulation of different pathways related to protein homeostasis, namely eIF2, eIf4/p70S6K, and unfolded protein response signaling. Anterior proteomic studies showed that $\mathrm{ZnO}$ NPs induce disturbance of proteins involved in protein synthesis by deregulating structural constituent of ribosomes in human monocyte-derived macrophage but not in Jurkat cells (Tuomela et al. 2013). The fundamental difference between these findings concerns the cell line type used. In our study, the main altered gene expression was involved in the ribosome biogenesis and several translation initiation factors such as $e I F 3 k$ and $e I F 2 \beta$, as well as $40 \mathrm{~S}$ and $60 \mathrm{~S}$ ribosomal subunits such as Rpl36a, Rpl9, or Rpl14 genes, and transcription factors such as Atf7 and Atf3. It should be noticed that the latest one, Atf3, has a binding site on the promoter sequence of the two upregulated genes that code for zinc-finger proteins $Z$ fand $2 \mathrm{~A}$ and $\mathrm{Znrf4}$ after $\mathrm{ZnFe}_{2} \mathrm{O}_{4}$ exposure. These zinc-finger proteins are also involved in the protein synthesis cluster (LifeMap sciences, GeneCards Suite ${ }^{\circledR}$ Knowledgebase, version 4.9).
It is also important to note that the proteomics results revealed a specific and significant deregulation of the VEGF pathway following exposure of cells to $\mathrm{ZnO}$ NPs through inhibition of Acta1 and Actn1, among others. This pathway was predicted to be inhibited in NR8383 cells following exposure to ZnO NPs during $24 \mathrm{~h}$ (Table S2). Coherently, Tada-Oikawa et al. (2015) described the vascular endothelial growth factor pathway to be negatively regulated by $\mathrm{ZnO}$ NPs on human endothelial cells suggesting that these effects are based on the concentration of released $\mathrm{Zn}^{2+}$. In contrast, other studies have demonstrated activation of the VEGF pathway following exposure of human dermal fibroblasts to ZnO NPs (Augustine et al. 2014). These differences could be due to the nature of exposed cell lines that are from two different embryonic origins. Therefore, inhibition of the VEGF pathway in NR8383 cells suggests a cytoskeleton defect and may be a migration default induced by $\mathrm{ZnO}$ NPs. As far as we know, no previous study has shown a disturbance of the VEGF pathway by ZnO NPs in macrophages.

\section{Conclusion}

Altogether, our results along with previous reports clearly demonstrate the hazard effects associated to the exposure of $\mathrm{ZnO}$ and $\mathrm{ZnFe}_{2} \mathrm{O}_{4}$ NPs. These compounds are already used in several products, from toothpaste to antibacterial gels and food, without a deep knowledge of how the human body could respond to exposure, whether short or long term. From the results obtained, $\mathrm{ZnO}$ NPs are by far the most cytotoxic NPs of the three NPs studied on NR8383, followed by $\mathrm{ZnFe}_{2} \mathrm{O}_{4} \mathrm{NPs}$ and then $\mathrm{Fe}_{2} \mathrm{O}_{3} \mathrm{NPs}$. Cytotoxicity is related to the presence of the $\mathrm{Zn}$ element.

Also, based on this study, we suggest the metallothioneins $\mathrm{Mtla}$ and $\mathrm{Mt} 2 \mathrm{~A}$ as exposure biomarkers of both NPs $\mathrm{ZnO}$ and $\mathrm{ZnFe}_{2} \mathrm{O}_{4}$, biomarkers that were validated by Figueira et al. (2012). Moreover, according to the transcriptome and proteome profiles, $\mathrm{ZnO}$ and $\mathrm{ZnFe}_{2} \mathrm{O}_{4}$ NPs induce ER stress that could be a molecular initiating event. This is highlighted by the deregulation of eIF2 pathway and dysfunction of cholesterol biosynthesis. Both NPs also induce oxidative stress by dysregulation of genes and proteins involved in mitochondrial functions, oxidative phosphorylation, and sirtuin homeostasis. However, the VEGF pathway 
was specific to $\mathrm{ZnO}$ exposure and iron homeostasis pathway specific to $\mathrm{ZnFe}_{2} \mathrm{O}_{4}$ exposure.

Finally, it is obvious that further studies under realistic biological conditions rather than artificial environment of culture cells should be done, to elucidate the mechanism of action of these nanometric structures.

Acknowledgments We thank Hadrien Uhrig for technical help, Jaafar Ghanbaja and Sylvie Migot for TEM, Pr Raphaël Schneider for ICP-OES facility access, and Céline Bonnet for microarray scanner access.

Funding information This work has received funding from the European Union's Horizon 2020 research and innovation program under grant agreement No. 686098.

\section{Compliance with ethical standards}

Conflict of interest The authors declare that they have no conflicting interests.

Open Access This article is licensed under a Creative Commons Attribution 4.0 International License, which permits use, sharing, adaptation, distribution and reproduction in any medium or format, as long as you give appropriate credit to the original author(s) and the source, provide a link to the Creative Commons licence, and indicate if changes were made. The images or other third party material in this article are included in the article's Creative Commons licence, unless indicated otherwise in a credit line to the material. If material is not included in the article's Creative Commons licence and your intended use is not permitted by statutory regulation or exceeds the permitted use, you will need to obtain permission directly from the copyright holder. To view a copy of this licence, visit http://creativecommons.org/licenses/by/4.0/.

\section{References}

Alhadlaq HA, Akhtar MJ, Ahamed M. Zinc ferrite nanoparticleinduced cytotoxicity and oxidative stress in different human cells. Cell Biosci. 2015;5:55. https://doi.org/10.1186/s13578015-0046-6.

Andreini C, Banci L, Bertini I, Rosato A. Counting the zincproteins encoded in the human genome. J Proteome Res. 2006;5:196-201. https://doi.org/10.1021/pr050361j.

Aude-Garcia C, Dalzon B, Ravanat JL, Collin-Faure V, Diemer H, Strub JM, et al. A combined proteomic and targeted analysis unravels new toxic mechanisms for zinc oxide nanoparticles in macrophages. J Proteome. 2016;134:174-85. https://doi. org/10.1016/j.jprot.2015.12.013.

Augustine R, Dominic EA, Reju I, Kaimal B, Kalarikkal N, Thomas S. Investigation of angiogenesis and its mechanism using zinc oxide nanoparticle-loaded electrospun tissue engineering scaffolds. RSC Adv. 2014;4:51528-36. https://doi.org/10.1039/C4RA07361D.

Berridge MV, Tan AS, KD McCoy RW. The biochemical and cellular basis of cell proliferation assays that use tetrazolium salts. Biochemica. 1996;4:15-9.

Brunner TJ, Wick P, Manser P, Spohn P, Grass RN, Limbach LK, et al. In vitro cytotoxicity of oxide nanoparticles: comparison to asbestos, silica, and the effect of particle solubility. 2006. https://doi.org/10.1021/ES052069I.

Buzea C, Pacheco II, Robbie K. Nanomaterials and nanoparticles: sources and toxicity. Biointerphases. 2007;2:MR17-71. https://doi.org/10.1116/1.2815690.

Chai W, Zakrzewski SS, Günzel D, Pieper R, Wang Z, Twardziok $\mathrm{S}$, et al. High-dose dietary zinc oxide mitigates infection with transmissible gastroenteritis virus in piglets. BMC Vet Res. 2014;10:75. https://doi.org/10.1186/1746-6148-10-75.

Chen G, Shen Y, Li X, Jiang Q, Cheng S, Gu Y, et al. The endoplasmic reticulum stress inducer thapsigargin enhances the toxicity of $\mathrm{ZnO}$ nanoparticles to macrophages and macrophageendothelial co-culture. Environ Toxicol Pharmacol. 2017;50: 103-10. https://doi.org/10.1016/j.etap.2017.01.020.

Chevallet M, Gallet B, Fuchs A, Jouneau PH, Um K, Mintz E, et al. Metal homeostasis disruption and mitochondrial dysfunction in hepatocytes exposed to sub-toxic doses of zinc oxide nanoparticles. Nanoscale. 2016;8:18495-506. https://doi.org/10.1039/c6nr05306h.

Chusuei CC, Wu C-H, Mallavarapu S, Hou FYS, Hsu C-M, Winiarz JG, et al. Cytotoxicity in the age of nano: the role of fourth period transition metal oxide nanoparticle physicochemical properties. Chem Biol Interact. 2013;206:319-26. https://doi.org/10.1016/j.cbi.2013.09.020.

Cohen J, Deloid G, Pyrgiotakis G, Demokritou P. Interactions of engineered nanomaterials in physiological media and implications for in vitro dosimetry. Nanotoxicology. 2013;7:41731. https://doi.org/10.3109/17435390.2012.666576.

Cox J, Hein MY, Luber CA, Paron I, Nagaraj N, Mann M. Accurate proteome-wide label-free quantification by delayed normalization and maximal peptide ratio extraction, termed MaxLFQ. Mol Cell Proteomics. 2014;13:2513-26. https://doi.org/10.1074/mcp.M113.031591.

Eidi H, Joubert O, Némos C, Grandemange S, Mograbi B, Foliguet B, et al. Drug delivery by polymeric nanoparticles induces autophagy in macrophages. Int J Pharm. 2012;422: 495-503. https://doi.org/10.1016/j.ijpharm.2011.11.020.

Figueira E, Branco D, Antunes SC, Gonçalves F, Freitas R. Are metallothioneins equally good biomarkers of metal and oxidative stress? Ecotoxicol Environ Saf. 2012;84:185-90. https://doi.org/10.1016/j.ecoenv.2012.07.012.

Ganguly K, Ettehadieh D, Upadhyay S, Takenaka S, Adler T, Karg E, et al. Early pulmonary response is critical for extra-pulmonary carbon nanoparticle mediated effects: comparison of inhalation versus intra-arterial infusion exposures in mice. Part Fibre Toxicol. 2017;14:19. https://doi.org/10.1186/s12989-017-0200-x.

Gaté L, Disdier C, Cosnier F, Gagnaire F, Devoy J, Saba W, et al. Biopersistence and translocation to extrapulmonary organs of titanium dioxide nanoparticles after subacute inhalation exposure to aerosol in adult and elderly rats. Toxicol Lett. 2017;265:61-9. https://doi.org/10.1016/j.toxlet.2016.11.009.

George J, Ahmad N. Mitochondrial sirtuins in cancer: emerging roles and therapeutic potential. Cancer Res. 2016;76:2500-6. https://doi.org/10.1158/0008-5472.CAN-15-2733. 
Gesquière L, Loreau N, Minnich A, Davignon J, Blache D. Oxidative stress leads to cholesterol accumulation in vascular smooth muscle cells. Free Radic Biol Med. 1999;27:134-45.

Gong Y, Ji Y, Liu F, Li J, Cao Y. Cytotoxicity, oxidative stress and inflammation induced by $\mathrm{ZnO}$ nanoparticles in endothelial cells: interaction with palmitate or lipopolysaccharide. J Appl Toxicol. 2017;37:895-901. https://doi.org/10.1002/jat.3415.

Hughes CS, Foehr S, Garfield DA, Furlong EE, Steinmetz LM, Krijgsveld J. Ultrasensitive proteome analysis using paramagnetic bead technology. Mol Syst Biol. 2014;10:757.

Hussain S, Vanoirbeek JAJ, Hoet PHM. Interactions of nanomaterials with the immune system. Wiley Interdiscip Rev Nanomed Nanobiotechnol. 2012;4:169-83. https://doi. org/10.1002/wnan.166.

Jennings P. Stress response pathways, toxicity pathways and adverse outcome pathways. Arch Toxicol. 2013;87:13-4. https://doi.org/10.1007/s00204-012-0974-4.

Li Y, Bao J, Bian Y, Erben U, Wang P, Song K, et al. S100A4+ macrophages are necessary for pulmonary fibrosis by activating lung fibroblasts. Front Immunol. 2018;9:1776. https://doi.org/10.3389/fimmu.2018.01776.

Lindeque JZ, Levanets O, Louw R, van der Westhuizen FH. The involvement of metallothioneins in mitochondrial function and disease. Curr Protein Pept Sci. 2010;11:292-309.

Lynch I, Dawson KA. Protein-nanoparticle interactions. Nano Today. 2008;3:40-7. https://doi.org/10.1016/S1748-0132(08 )70014-8.

Maiorino M, Conrad M, Ursini F. GPx4, lipid peroxidation, and cell death: discoveries, rediscoveries, and open issues. Antioxid Redox Signal. 2018;29:61-74. https://doi. org/10.1089/ars.2017.7115.

Niska K, Pyszka K, Tukaj C, Wozniak M, Radomski MW, Inkielewicz-Stepniak I. Titanium dioxide nanoparticles enhance production of superoxide anion and alter the antioxidant system in human osteoblast cells. Int J Nanomedicine. 2015;10:1095-107. https://doi.org/10.2147/IJN.S73557.

Oberdörster G, Oberdörster E, Oberdörster J. Nanotoxicology: an emerging discipline evolving from studies of ultrafine particles. Environ Health Perspect. 2005;113:823-39. https://doi. org/10.1289/ehp.7339.

Prach M, Stone V, Proudfoot L. Zinc oxide nanoparticles and monocytes: impact of size, charge and solubility on activation status. Toxicol Appl Pharmacol. 2013;266:19-26. https://doi.org/10.1016/j.taap.2012.10.020.

Présumé M, Simon-Deckers A, Tomkiewicz-Raulet C, Le Grand B, Tran Van Nhieu J, Beaune G, et al. Exposure to metal oxide nanoparticles administered at occupationally relevant doses induces pulmonary effects in mice. Nanotoxicology. 2016;10: 1535-44. https://doi.org/10.1080/17435390.2016.1242797.

Reed LJ, Muench H. a simple method of estimating fifty per cent endpoints12. Am J Epidemiol. 1938;27:493-7. https://doi. org/10.1093/oxfordjournals.aje.a118408.

Safar R, Doumandji Z, Saidou T, Ferrari L, Nahle S, Rihn BH, et al. Cytotoxicity and global transcriptional responses induced by zinc oxide nanoparticles NM 110 in PMAdifferentiated THP-1 cells. Toxicol Lett. 2018;308:65-73. https://doi.org/10.1016/j.toxlet.2018.11.003.

Sato M, Kondoh M. Recent studies on metallothionein: protection against toxicity of heavy metals and oxygen free radicals. Tohoku J Exp Med. 2002;196:9-22. https://doi.org/10.1620 /tjem.196.9.
Schins RPF, Lightbody JH, Borm PJA, Shi T, Donaldson K, Stone $\mathrm{V}$. Inflammatory effects of coarse and fine particulate matter in relation to chemical and biological constituents. Toxicol Appl Pharmacol. 2004;195:1-11. https://doi.org/10.1016/j. taap.2003.10.002.

Singh R, Lillard JW. Nanoparticle-based targeted drug delivery. Exp Mol Pathol. 2009;86:215-23. https://doi.org/10.1016/j. yexmp.2008.12.004.

Sozen E, Ozer NK. Impact of high cholesterol and endoplasmic reticulum stress on metabolic diseases: an updated minireview. Redox Biol. 2017;12:456-61. https://doi. org/10.1016/j.redox.2017.02.025.

Tada-Oikawa S, Ichihara G, Suzuki Y, Izuoka K, Wu W, Yamada $\mathrm{Y}$, et al. $\mathrm{Zn}$ (II) released from zinc oxide nano/micro particles suppresses vasculogenesis in human endothelial colonyforming cells. Toxicol Rep. 2015;2:692-701. https://doi. org/10.1016/J.TOXREP.2015.04.003.

Tannenbaum J, Bennett BT. Russell and Burch's 3Rs then and now: the need for clarity in definition and purpose. J Am Assoc Lab Anim Sci. 2015;54:120-32.

Tuomela S, Autio R, Buerki-Thurnherr T, Arslan O, Kunzmann A, Andersson-Willman B, et al. Gene expression profiling of immune-competent human cells exposed to engineered zinc oxide or titanium dioxide nanoparticles. PLoS One. 2013;8: e68415. https://doi.org/10.1371/journal.pone.0068415.

Vallee BL. The function of metallothionein. Neurochem Int. 1995;27:23-33.

Vašák M. Advances in metallothionein structure and functions. J Trace Elem Med Biol. 2005;19:13-7. https://doi.org/10.1016 j.jtemb.2005.03.003.

Wallin H, Kyjovska ZO, Poulsen SS, Jacobsen NR, Saber AT, Bengtson S, et al. Surface modification does not influence the genotoxic and inflammatory effects of $\mathrm{TiO} 2$ nanoparticles after pulmonary exposure by instillation in mice. Mutagenesis. 2017;32:47-57. https://doi.org/10.1093 /mutage/gew046.

Wiemann M, Vennemann A, Sauer UG, Wiench K, Ma-Hock L, Landsiedel R. An in vitro alveolar macrophage assay for predicting the short-term inhalation toxicity of nanomaterials. J Nanobiotechnol. 2016;14:16. https://doi.org/10.1186 /s12951-016-0164-2.

Yang X, Shao H, Liu W, Gu W, Shu X, Mo Y, et al. Endoplasmic reticulum stress and oxidative stress are involved in $\mathrm{ZnO}$ nanoparticle-induced hepatotoxicity. Toxicol Lett. 2015;234:40-9. https://doi.org/10.1016/j.toxlet.2015.02.004.

Yang P, Hong W, Zhou P, Chen B, Xu H. Nano and bulk ZnO trigger diverse $\mathrm{Zn}$-transport-related gene transcription in distinct regions of the small intestine in mice after oral exposure. Biochem Biophys Res Commun. 2017;493:1364-9. https://doi.org/10.1016/j.bbrc.2017.09.165.

Zhang W, Ohno S, Steer B, Klee S, Staab-Weijnitz CA, Wagner D, et al. S100a4 is secreted by alternatively activated alveolar macrophages and promotes activation of lung fibroblasts in pulmonary fibrosis. Front Immunol. 2018;9:1216. https://doi. org/10.3389/fimmu.2018.01216.

Publisher's note Springer Nature remains neutral with regard to jurisdictional claims in published maps and institutional affiliations. 